\title{
ULTRALIBERALISMO, EVANGELICALISMO POLÍTICO E MISOGINIA: A FORÇA TRIUNFANTE DO PATRIARCALISMO NA SOCIEDADE BRASILEIRA PÓS-IMPEACHMENT
}

\author{
ULTRALIBERALISM, POLITICAL EVANGELICALISM AND MISOGINY: THE \\ TRIUMPHANT FORCE OF PATRIARCHALISM IN BRAZILIAN POST- \\ IMPEACHMENT SOCIETY
}

\author{
ULTRALIBERALISMO, EVANGELICALISMO POLÍTICO Y MISOGINIA: LA \\ FUERZA TRIUNFANTE DEL PATRIARCALISMO EN LA SOCIEDAD BRASILEÑA \\ POST-IMPEACHMENT
}

\begin{abstract}
MAIQUeL ÂNGELo DeZoRdI WeRMUTH
https://orcid.org/0000-0002-7365-5601 / http://lattes.cnpq.br/0354947255136468 / madwermuth@gmail.com

Doutor em Direito Público (UNISINOS). Professor do Mestrado em Direitos Humanos da UNIJUí - Universidade Regional do Nororeste do Estado do Rio Grande do Sul e do Curso de Graduação em Direito da UNISINOS. Ijuí, RS, Brasil.
\end{abstract}

JOICE GRACIELE NIELSSON

http://orcid.org/0000-0003-3808-1064 / http://lattes.cnpq.br/3002965109553965 / joice.gn@gmail.com

Doutora em Direito (UNISINOS). Professora do Curso de Direito (UNIJUÍ). Ijuí, RS, Brasil.

\section{RESUMO}

O artigo perspectiva o cenário político-social brasileiro pós-impeachment de 2016, buscando compreender as causas condicionantes do referido processo e os seus reflexos na política e na sociedade brasileiras. Visa a responder ao seguinte problema de pesquisa: em que medida o processo de impeachment ocorrido no Brasil em 2016, mais do que um simples processo jurídico-político, representou um marco na (re)articulação e no avanço do patriarcalismo, ancorado especialmente em uma aliança entre ultraliberais e fundamentalistas que, com base em uma retórica misógina e conservadora, abriu caminho para o avanço das políticas de desmonte do Estado Social minimamente estruturado no Brasil, evidenciando a ocorrência de um processo denominado, a partir da teoria social-democrática de Nancy Fraser, de "evangelicalismo político"? Para responder à pergunta, o texto encontra-se estruturado em três partes: em um primeiro momento, realiza uma análise do patriarcalismo, considerando ser este o modelo (ainda) predominante na sociedade brasileira; em um segundo momento, aborda os acontecimentos jurídico-políticos do impeachment sofrido por Dilma Rousseff, demonstrando que este processo configurou-se a partir de uma (re)articulação do avanço das forças patriarcalistas; por fim, apresenta o "evangelicalismo político", tal qual cunhado por Nancy Fraser, como o movimento que dá sustentação ao patriarcalismo, na medida em que viabiliza a aliança do fundamentalismo religioso com o movimento de avanço ultraliberal. Utiliza-se, na investigação, o método fenomenológico, notadamente a partir das contribuições de Martin Heidegger e Hans-Georg Gadamer.

Palavras-chave: Brasil; Evangelicalismo; Impeachment; Misoginia; Patriarcalismo.

\section{ABSTRACT}

The article looks at the post-impeachment Brazilian political-social scenario of 2016, seeking to understand the conditioning causes of this process and its reflexes in Brazilian politics and society. It aims to respond to the following research problem: to what extent the process of impeachment that took place in Brazil in 2016, rather than a simple juridical-political process, represented a milestone in (re) articulation and advancement of patriarchalism, anchored 
especially in an alliance between the ultraliberals and the fundamentalists that, based on a misogynist and conservative rhetoric, paved the way for the advancement of the policies of dismantling the social state that was minimally structured in Brazil, evidencing the occurrence of a process called, based on the social-democratic theory of Nancy Fraser, for "political evangelicalism"? To answer the question, the text is structured in three parts: at first, it performs an analysis of patriarchalism, considering that it is the (still) predominant model in Brazilian society; in a second moment, it addresses the juridical-political events of the impeachment suffered by Dilma Rousseff, demonstrating that this process was formed from a (re) articulation of the advance of the patriarchal forces; finally, it presents "political evangelicalism", as coined by Nancy Fraser, as the movement that sustains patriarchalism, insofar as it makes possible the alliance of religious fundamentalism with the movement of ultraliberal advancement. In the research, the phenomenological method is used, notably from the contributions of Martin Heidegger and Hans-Georg Gadamer.

Keywords: Brazil; Evangelicalism; Impeachment; Misogyny; Patriarchy.

\section{RESUMEN}

El artículo perspectiva el escenario político-social brasileño post-impeachment de 2016, buscando comprender las causas condicionantes del referido proceso y sus reflejos en la política y en la sociedad brasileñas. Busca-se contestar lo siguiente problema de pesquisa: en el caso de Brasil, el proceso de impeachment que ocurrió en 2016, más que un simple proceso jurídico-político, representó un hito en la (re) articulación y en el avance del patriarcalismo, anclado especialmente en una situación de alianza entre ultraliberales y fundamentalistas que, con base en una retórica misógina y conservadora, abrió el camino para el avance de las políticas de desmonte del Estado Social mínimamente estructurado, evidenciando la ocurrencia de un proceso denominado, a partir de la teoría socialdemocrática de Nancy Fraser, de "evangelicalismo político"? Para responder a la pregunta, el texto se encuentra estructurado en tres partes: en un primer momento, realiza un análisis del patriarcalismo, considerando que éste es el modelo (aún) predominante en la sociedad brasileña; en un segundo momento, aborda los acontecimientos jurídico-políticos del impeachment sufrido por Dilma Rousseff, demostrando que este proceso se configuró a partir de una (re) articulación del avance de las fuerzas patriarcalistas; por último, presenta el "evangelicalismo político", tal cual acuñado por Nancy Fraser, como el movimiento que da sustentación al patriarcalismo, en la medida en que viabiliza la alianza del fundamentalismo religioso con el movimiento de avance ultraliberal. Se utiliza, en la investigación, el método fenomenológico, notadamente a partir de las contribuciones de Martin Heidegger y Hans-Georg Gadamer.

Palabras clave: Brasil; Evangelicalismo; Impeachment; Misoginia; Patriarcado.

\section{SUMÁRIO}

INTRODUÇAO; 1 A (RE)ARTICULAÇÃO DO PATRIARCALISMO: O PREDADOR DO NOSSO TEMPO; 20 PATRIARCALISMO, A MISOGINIA E O IMPEACHMENT DE 2016: "TCHAU QUERIDA"(?!); 30 EVANGELICALISMO POLÍTICO E A SUSTENTAÇÃO ULTRALIBERAL DO PATRIARCALISMO; CONCLUSÃO; REFERÊNCIAS.

\section{INTRODUÇÃO}

Em seu livro "A difícil democracia: reinventar as esquerdas", o sociólogo português Boaventura de Sousa Santos ${ }^{1}$ refere que vivemos na contemporaneidade uma conjuntura perigosa, na qual se evidencia o desaparecimento ou a descaracterização dos "vários imaginários de emancipação social que as classes populares geraram com suas lutas contra a dominação

\footnotetext{
1 SANTOS, Boaventura de Sousa. A difícil democracia: reinventar as esquerdas. São Paulo: Boitempo, 2016, p. 22.
} 
capitalista, colonialista e patriarcal". Atento a este contexto, o objetivo deste artigo é empreender uma análise do cenário político-social brasileiro pós-impeachment de 2016, a fim de compreender as causas condicionantes do referido processo e os reflexos do impedimento da Presidenta Dilma Rousseff na política e na sociedade brasileiras.

A temática é perspectivada a partir do seguinte questionamento: em que medida o processo de impeachment ocorrido no Brasil em 2016, mais do que um simples processo jurídicopolítico, representou um marco na (re)articulação e no avanço do patriarcalismo, ancorado especialmente em uma aliança entre ultraliberais e fundamentalistas que, com base em uma retórica misógina e conservadora, abriu caminho para o avanço das políticas de desmonte do Estado Social minimamente estruturado no Brasil, evidenciando a ocorrência de um processo denominado, a partir da teoria social-democrática de Nancy Fraser, de "evangelicalismo político"?

Em um primeiro momento, o artigo realiza uma análise do patriarcalismo, a partir dos estudos de Joaquín Herrera Flores, considerando ser este o modelo (ainda) predominante na sociedade brasileira, a partir de uma articulação entre patriarcado, capitalismo e outras formas de opressões e discriminações historicamente perpetradas no país. Em um segundo momento, aborda os acontecimentos jurídico-políticos do impeachment sofrido por Dilma Rousseff, demonstrando que este processo configurou-se a partir de uma (re)articulação do avanço das forças patriarcalistas, as quais, aliadas à misoginia e a um ultraliberalismo econômico, derrotaram as forças progressistas evidenciadas no país a partir do primeiro governo de Luís Inácio Lula da Silva.

Por fim, o artigo apresenta o "evangelicalismo político", tal qual cunhado por Nancy Fraser, como o movimento que dá sustentação ao patriarcalismo, na medida em que viabiliza a aliança do fundamentalismo religioso com o movimento de avanço ultraliberal. A insegurança gerada por este movimento é atribuída, através do evangelicalismo, ao avanço das forças progressistas e à concessão de direitos a grupos historicamente excluídos, utilizando-se uma retórica codificada de gênero a fim de sustentar a retirada de direitos e a retomada de políticas extremamente austeras no que se refere à dimensão do bem-estar social.

Utiliza-se, na investigação, o método fenomenológico, notadamente a partir das contribuições de Martin Heidegger e Hans-Georg Gadamer. Referida opção metodológica está assentada sobre a importância da linguagem, na medida em que não se busca um estudo a partir do qual o sujeito - no caso, os autores do artigo - esteja “afastado" ou "cindido" do seu objeto. 
ULTRALIBERALISMO, EVANGELICALISMO POLÍTICO E MISOGINIA: A FORÇA TRIUNFANTE DO PATRIARCALISMO NA SOCIEDADE BRASILEIRA PÓS-IMPEACHMENT MAIQUEL ÂNGELO DEZORDI WERMUTH JOICE GRACIELE NIELSSON

Pelo contrário, o objeto e o sujeito são constituídos pela palavra e por meio dela recebem a atribuição de sentido - daí o aspecto (circular) hermenêutico.

Nesse sentido, a contribuição da hermenêutica filosófica para a elaboração do presente artigo foi demonstrar que as condições que tornam o pensamento possivel não são autogeradas, mas são estabelecidas bem antes de nos engajarmos em atos de introspecção, ou seja, que nós já estamos envolvidos no mundo bem antes de nos separarmos dele teoricamente para procurar entendê-lo filosoficamente. Não há, portanto, terminantemente, qualquer possibilidade de cisão entre sujeito e objeto.

\section{A (RE)ARTICULAÇÃO DO PATRIARCALISMO: O PREDADOR DO NOSSO TEMPO}

Toda cultura possui uma espécie de predador que simboliza seus aspectos mais devastadores e destrutivos, afirma Clarice Estés. ${ }^{2}$ Este predador se instala em mentes, atitudes e nos sonhos de todos aqueles que a formam, impondo-se como a perspectiva "natural" presente no mundo e nas relações sociais. Na sociedade brasileira da atualidade, o predador "mais extenso, e não por isso mais visível, que domina nossa cultura" é, segundo este artigo, aquele apontado por Joaquín Herrera Flores: ${ }^{3}$ o patriarcalismo.

No caso da proposta teórica deste trabalho, basta apenas aprofundar um pouco a reflexão sobre a realidade brasileira pré e pós impeachment de 2016, para que se vislumbre a presença deste predador, implantando um sistema de valores como se fosse o único que tivesse o direito a conformar percepções e ações. Tudo o que sai de seus limites, afirma Herrera Flores, ${ }^{4}$ é considerado "excêntrico" ou, pior, "irracional”, por valores dissimulados em símbolos culturais, que constroem e generalizam um sistema de valores que, ao se instalar como "a percepção natural" dos fenômenos, margina qualquer outro que possa se opor, eliminando ou degradando as linguagens, discursos e categorias que pretendam sair de seus domínios.

Herrera Flores ${ }^{5}$, pautado pela metodologia materialista, define o predador a partir do seu modo concreto de funcionamento e suas várias feições, das quais nenhuma pode ser ignorada: é

\footnotetext{
${ }^{2}$ ESTÉS, Clarisse Pinkola. Mulheres que correm com os lobos. Rio de Janeiro: Rocco, 1999.

3 FLORES, Joaquín Herrera. De habitaciones propias y otros espacios negados: una teoría crítica de las opresiones patriarcales. Bilbao: Instituto de Derechos Humanos Universidad de Deusto, 2005, p. 13.

${ }^{4}$ FLORES, Joaquín Herrera. De habitaciones propias y otros espacios negados: una teoría crítica de las opresiones patriarcales. Bilbao: Instituto de Derechos Humanos Universidad de Deusto, 2005, p. 14.

${ }^{5}$ FLORES, Joaquín Herrera. De habitaciones propias y otros espacios negados: una teoría crítica de las opresiones patriarcales. Bilbao: Instituto de Derechos Humanos Universidad de Deusto, 2005.
} 
ULTRALIBERALISMO, EVANGELICALISMO POLÍTICO E MISOGINIA: A FORÇA TRIUNFANTE DO PATRIARCALISMO NA SOCIEDADE BRASILEIRA PÓS-IMPEACHMENT MAIQUEL ÂNGELO DEZORDI WERMUTH JOICE GRACIELE NIELSSON

classista, racista, sexista, em suma, é configurador de opressões sobrepostas ${ }^{6}$. Em última instância, age "naturalizando valores na sociedade e, consequentemente, guiando a construção social do Direito e da Política ao estabelecer uma divisão entre a dimensão dos visíveis - os iguais perante a lei - e dos invisíveis, que são os outros, os diferentes"7. Por isso, manifesta profundo temor diante da mínima possibilidade de ameaça à sua ordem: seja a de que a assimetria vital entre mulheres e homens, entre ricos e pobres, entre incluídos e excluídos esteja sendo questionada, ou de que o direito a explorar a participação de todos(as) nos âmbitos público e privado esteja começando a ser percebido como injusto e discriminatório.

Sobremaneira, esse temor fica mais nítido em sociedades como a brasileira, desde sempre marcada por uma rígida hierarquização social, "marca forte e renitente" que nos foi legada como "herança da escravidão", segundo a análise de Schwarcz e Starling. ${ }^{8}$ Basta, para tanto, analisar as diversas tentativas das hegemonias conservadoras em desvirtuar as reais funções de programas sociais como o Bolsa Família, por exemplo, que passa a ser explorado como um fomento à reprodução irresponsável e à "vadiagem" - esta última, expressão ainda bem viva no imaginário nacional, desde a incipiente República. ${ }^{9}$

Considerar o patriarcalismo como a matriz teórica de análise e compreensão dos fenômenos da atualidade importa não refletir sobre as opressões e explorações que sofrem as mulheres (e outros coletivos afetados pelo predador) de uma maneira abstrata e homogeneizante, insistindo que o gênero seja o único determinante dos destinos humanos. Importa, também, não considerar que todos os conflitos sociais têm origens culturais e,

\footnotetext{
${ }^{6}$ Para o autor, "o predador funciona, primeiro, como um espelho desforme que apresenta o homem branco e ocidental e o sistema de valores que o protege, como se tivesse um corpo e uma influência dupla, maior do que aquela que realmente possui, induzindo aos demais a se sentirem humilhados frente a magnificência e eternidade de seus privilégios. A ideologia do predador se situa, pois, à margem da experiência concreta dos seres humanos aos quais devora; instaura uma verdade abstrata e rechaça tudo o que não corresponde a ela, e busca reproduzir os seres humanos a sua imagem e semelhança Tudo o que não consegue explicar se transforma em seu inimigo. E, segundo, ocultando que o modo mais efetivo de escaparmos desta imagem deformada da realidade é fugir das idealizações e abstrações de, por exemplo, "feminino" natural, o "trabalhador responsável”, o bom indígena, esforçando-nos a sermos materialistas, o que, entre outras coisas, nos impulsiona a criar as condições materiais que permitam ver e atuar no mundo a partir de outra perspectiva". HERRERA FLORES, Joaquín. De habitaciones propias y otros espacios negados: una teoría crítica de las opresiones patriarcales. Bilbao: Instituto de Derechos Humanos Universidad de Deusto, 2005, p. 22.

7 GRUBBA, Leilane Serratine; AQUINO, Sérgio Fernandes. 0 individualismo e patriarcalismo dos direitos humanos como marco da ideologia-mundo. Revista do Programa de Pós-Graduação em Direito da UFC, v. 36, n. 2, jul./dez. 2016, p. 296.

8 SCHWARCZ, Lilia M.; STARLING, Heloisa M.. Brasil: uma biografia. São Paulo: Companhia das Letras, 2015, p. 15.

${ }^{9}$ CHALHOUB, Sidney. Trabalho, lar e botequim: o cotidiano dos trabalhadores no Rio de Janeiro da belle époque. 2. ed. Campinas: UNICAMP, 2001.
} 
ULTRALIBERALISMO, EVANGELICALISMO POLÍTICO E MISOGINIA: A FORÇA TRIUNFANTE DO PATRIARCALISMO NA SOCIEDADE BRASILEIRA PÓS-IMPEACHMENT MAIQUEL ÂNGELO DEZORDI WERMUTH JOICE GRACIELE NIELSSON

portanto, sua solução deve ser meramente cultural, ou seja, no plano simbólico, deixando de lado toda a problemática econômica ou política.

Neste sentido, Nancy Fraser $^{10}$ tem alertado sobre os grandes problemas trazidos pelas fragmentações internas das lutas antidiscriminatórias, especialmente aquelas entre adeptos da política de redistribuição e adeptos da politica de reconhecimento. Para a autora, ${ }^{11}$ a virada culturalista $^{12}$ empreendida pelo pensamento crítico ao final dos anos 1980 , especialmente pelo feminismo, deixou-o indefeso diante da reorganização do capitalismo, em escala global, e o avanço das políticas neoliberais, aspecto que, em muito, pode ser vislumbrado no cenário brasileiro, conforme análise que será adiante realizada.

No entanto, alerta Fraser ${ }^{13}$ que o momento da virada no imaginário feminista rumo à política culturalista não poderia ter sido pior, ocorrendo precisamente no período em que o neoliberalismo se fortalecia. Tal virada levou a teoria acadêmica progressista a enfatizar debates sobre "diferença" e essencialismos, o que serviu para abrir os estudos de gênero para muitas novas vozes. Porém, mesmo nos seus melhores momentos, as teorias permaneceram no terreno do reconhecimento e da subordinação cultural, dissociadas da economia política, deixando-as sem defesa contra o avanço do conservadorismo e do fundamentalismo do livremercado, agora hegemônico.

"Encantada pela política de reconhecimento, a teoria feminista foi direcionada para canais culturalistas precisamente quando as circunstâncias requeriam políticas de

${ }^{10}$ FRASER, Nancy. Fortunas del feminismo. Traficantes de Sueños: Madrid, 2015.

11 FRASER, Nancy. O feminismo, o capitalismo e a astúcia da história. Mediações, v. 14, n. 2, p. 11-33, Londrina, jul./dez. 2009.

12 De acordo com a autora, ao lado de outros movimentos progressistas, os feminismos da segunda metade do século passado modificaram o imaginário político, desafiando as exclusões de gênero dentro da socialdemocracia, problematizando o paternalismo do Estado do bem-estar social e a família burguesa, expondo o profundo androcentrismo da sociedade capitalista. Politizando 'o pessoal', expandiram as fronteiras de contestação para além da redistribuição sócio-econômica. Sua evolução, no entanto, tomou um caminho diverso do imaginado, e "[...] en la década de 1980, sin embargo, la historia parecía haber eludido ese proyecto político", colocando em cena uma nova dimensão política para o feminismo: a política de reconhecimento. FRASER, Nancy. Fortunas del feminismo. Traficantes de Sueños: Madrid, 2015, p. 18.

Se a primeira fase aproximou o gênero do imaginário igualitarista e socialista, a segunda enfatizou a necessidade de "reconhecer a diferença", tornando "reconhecimento" e sua política de identidade e valorização da diferença em detrimento da igualdade, na principal gramática das reivindicações feministas no final do século. Quer o problema seja a violência contra a mulher, quer a disparidade na representação política, feministas, incapazes de enfrentar as injustiças econômicas, se voltaram à gramática do reconhecimento para expressar suas reivindicações. "O resultado foi uma grande mudança no imaginário feminista: enquanto a geração anterior buscava um ideal de eqüidade social expandido, esta investia suas energias nas mudanças culturais”. FRASER, Nancy. Mapeando a imaginação feminista: da redistribuição ao reconhecimento e à representação. Estudos Feministas, v. 15, n. 2, Florianópolis, maio/ago. 2007, p. 296.

13 FRASER, Nancy. O feminismo, o capitalismo e a astúcia da história. Mediações, v. 14, n. 2, p. 11-33, Londrina,jul./dez. 2009. 
ULTRALIBERALISMO, EVANGELICALISMO POLÍTICO E MISOGINIA: A FORÇA TRIUNFANTE DO PATRIARCALISMO NA SOCIEDADE BRASILEIRA PÓS-IMPEACHMENT MAIQUEL ÂNGELO DEZORDI WERMUTH JOICE GRACIELE NIELSSON

redistribuição" ${ }^{14}$. Desse modo, as críticas iniciais do feminismo foram ressignificadas pelo espírito do novo capitalismo de tal forma que sua força emancipadora foi abalada. ${ }^{15}$

Nesse sentido, uma real compreensão das injustiças que permeiam nosso tempo, ou seja, da complexidade de nosso predador, requer considerá-lo, ao menos, a partir de três dimensões: econômica, e as injustiças de má-distribuição, cultural, e as injustiças de não-reconhecimento, e política, e as injustiças de sub-representação. Todas atuam de forma conjunta e nenhuma delas pode ser negligenciada, sob pena de não compreendermos nem sermos capazes de fazer frente ao predador que nos ameaça.

No mesmo sentido aponta Herrera Flores, ${ }^{16}$ para quem o gênero, o racismo, o sexismo, o classismo e toda a discriminação contra os coletivos excluídos da modernidade têm origens políticas, sociais, econômicas e culturais, pelo que sua solução tem que ser política, social, econômica e também cultural. "Além de um choque entre culturas, estamos frente a choques entre discriminações e explorações que exigem, não apenas receitas culturais, mas estratégias políticas, sociais e econômicas de intervenção e de resolução"17.

Portanto, compreendemos que o vazio inominado de nosso tempo, ou problema sem nome ao qual Betty Friedan ${ }^{18}$ já se referia no contexto americano da segunda metade do século passado, traduzido na dificuldade conceitual que temos para compreender os processos de incerteza que vivenciamos, não é outra coisa senão uma manifestação do patriarcalismo, entendido como a base e o sustento de todo tipo de dominação autoritária ou totalitária, ou, na base de todos os processos de dominação política ou penal, sempre se apresentando de maneira difusa. ${ }^{19}$

É neste sentido que se optou - nos limites deste trabalho - pela utilização do termo patriarcalismo, tal qual definido por Herrera Flores, ${ }^{20}$ e não a tradicional expressão patriarcado.

\footnotetext{
14 FRASER, Nancy. Mapeando a imaginação feminista: da redistribuição ao reconhecimento e à representação. Estudos Feministas, v. 15, n. 2, p. 240, Florianópolis, maio/ago. 2007, p. 29.

${ }^{15}$ Fraser cita como exemplo concreto o movimento ocorrido nos Estados Unidos na última década do século passado e início do século XXI, e que teve seu auge na reeleição do Governo Bush, sob o slogan retórico de "defesa da família" e de intensificação de políticas capitalistas neoliberais. FRASER, Nancy. 0 feminismo, o capitalismo e a astúcia da história. Mediações, v. 14, n. 2, p. 11-33, Londrina,jul./dez. 2009.

${ }^{16}$ HERRERA FLORES, Joaquín. De habitaciones propias y otros espacios negados: una teoría crítica de las opresiones patriarcales. Bilbao: Instituto de Derechos Humanos Universidad de Deusto, 2005, p. 24.

${ }^{17}$ HERRERA FLORES, Joaquín. De habitaciones propias y otros espacios negados: una teoría crítica de las opresiones patriarcales. Bilbao: Instituto de Derechos Humanos Universidad de Deusto, 2005, p. 24.

${ }^{18}$ FRIEDAN, Betty. Mística feminina. Petrópolis: Vozes, 1971.

${ }^{19}$ FIRESTONE, Sulamith. Dialéctica del sexo. Barcelona: Kairos, 2009.

${ }^{20}$ HERRERA FLORES, Joaquín. De habitaciones propias y otros espacios negados: una teoría crítica de las opresiones patriarcales. Bilbao: Instituto de Derechos Humanos Universidad de Deusto, 2005, p. 29.
} 
ULTRALIBERALISMO, EVANGELICALISMO POLÍTICO E MISOGINIA: A FORÇA TRIUNFANTE DO PATRIARCALISMO NA SOCIEDADE BRASILEIRA PÓS-IMPEACHMENT MAIQUEL ÂNGELO DEZORDI WERMUTH JOICE GRACIELE NIELSSON

Isso porque, segundo o professor espanhol, “utilizamos o termo patriarcalismo e não o patriarcado, com o objetivo de rechaçar as posições estáticas que nos induzem a pensar na estrutura de opressão autônoma com respeito ao resto de opressões e dominações que dominam nas relações sociais capitalistas".

Ao contrário de patriarcado, que aparenta não ter origens históricas concretas, patriarcalismo tem mais a ver com o conjunto de relações que articulam um conjunto de opressões, especialmente: sexo, raça, gênero, etnia e classe social, e o modo com que tais relações sociais particulares se combinam em uma dimensão pública de poder, exploração ou status, com uma dimensão de servidão pessoal, abarcando assim as três dimensões de injustiças da contemporaneidade, propostas por Nancy Fraser ${ }^{21}$ : econômicas, culturais e políticas. Conforme Herrera Flores, ${ }^{22}$

patriarcalismo é um termo muito mais adequado, uma vez que nos faz ver como as relações patriarcais se articulam com outras formas de relação social em um determinado momento histórico. As estruturas de classe, racismo, gênero e sexualidade não podem ser tratadas como variáveis independentes, porque a opressão de cada uma está inscrita nas outras. Ou seja, é construída por, e é constitutiva destas.

É neste contexto que o termo é capaz de abordar não apenas as desigualdades de gênero, de sexo, de raça, mas também outras desigualdades, inseridas em um contexto de vinculação com o capitalismo. Capitalismo e patriarcado se unem em uma conexão, chamada aqui de patriarcalista, constituindo-se no maior predador do nosso tempo, um tempo que é definido por Boaventura de Sousa Santos ${ }^{23}$ como marcado pela existência de "sociedades que são politicamente democráticas mas socialmente fascistas", sendo o termo "fascismo" empregado pelo sociólogo português não no sentido de regime político de partido único que vigorou em alguns países da Europa, mas "a relações sociais de poder de tal modo desiguais que, no contexto social e político em que ocorrem, a parte (indivíduos ou grupos) mais poderosa exerce um direito de veto sobre aspectos essenciais da vida da parte menos poderosa."

\footnotetext{
${ }^{21}$ FRASER, Nancy. Fortunas del feminismo. Traficantes de Sueños: Madrid, 2015.

${ }^{22}$ HERRERA FLORES, Joaquín. De habitaciones propias y otros espacios negados: una teoría crítica de las opresiones patriarcales. Bilbao: Instituto de Derechos Humanos Universidad de Deusto, 2005, p. 29.

23 SANTOS, Boaventura de Sousa. Os perigos da desordem jurídica no Brasil. In. PRONER, Carol; CITTADINO, Gisele; TENENBAUM, Marcio; RAMOS FILHO, Wilson. A resistência ao golpe de 2016. São Paulo: Projeto Editorial Praxis, 2016, p. 131-132.
} 
ULTRALIBERALISMO, EVANGELICALISMO POLÍTICO E MISOGINIA: A FORÇA TRIUNFANTE DO PATRIARCALISMO NA SOCIEDADE BRASILEIRA PÓS-IMPEACHMENT MAIQUEL ÂNGELO DEZORDI WERMUTH JOICE GRACIELE NIELSSON

O sociólogo português ${ }^{24}$ enumera algumas situações que evidenciam a diversidade dos domínios nos quais é possível identificar o "fascismo social”: relações de trabalho à margem das leis laborais e/ou que envolvem exploração da mão de obra de imigrantes em situação de irregularidade, relações familiares dominadas pela violência doméstica em suas múltiplas formas/manifestações, relações sociais assentadas no racismo que se revelam nas estruturas urbanas, relações do capital financeiro com o país em que (des)investe sem outros motivos para além do mero lucro especulativo, privatização de bens essenciais, etc.

Todas essas formas de sociabilidade não se sujeitam a controles democráticos, dado que ocorrem do "lado de fora" daquilo que a teoria política liberal designa como "campo político" ou "sistema político". Em razão disso, a vida dos indivíduos, classes ou grupos sociais, que ocorrem nesses domínios considerados não políticos, estão sujeitas ao domínio do fascismo social, de modo que "a democracia representativa tende a ser sociologicamente uma ilha democrática num arquipélago de despotismos"25.

Em razão disso, Santos ${ }^{26}$ salienta que, mesmo em sociedades politicamente democráticas como a brasileira, inúmeros cidadãos vivem

sujeitos a constrangimentos, censuras e autocensuras, privação de direitos elementares de expressão e de movimento contra os quais não podem resistir sob pena de pesadas consequências; vivem, em suma, sujeitos a ações arbitrárias que são estruturalmente semelhantes às que sofreram os democratas durante a vigência dos regimes fascistas. Como se trata de um fascismo subpolítico, não é reconhecido como tal.

Em um contexto tal, afirma Herrera Flores, ${ }^{27}$ o patriarcalismo deve ser definido a partir de três esferas de ação: a) politicamente supõe uma configuração da realidade na qual prima o abstrato sobre o concreto, a desigualdade sobre a igualdade; b) axiologicamente impõe um conjunto de valores, crenças e atitudes não deduzidas, nem deduziveis, da realidade a partir das quais um grupo humano se advoga por natureza superior sobre o restante; e, c) sociologicamente se constitui na base da exclusão, ou seja, o conjunto de mecanismos enraizados na estrutura da

24 SANTOS, Boaventura de Sousa. Os perigos da desordem jurídica no Brasil. In. PRONER, Carol; CITTADINO, Gisele; TENENBAUM, Marcio; RAMOS FILHO, Wilson. A resistência ao golpe de 2016. São Paulo: Projeto Editorial Praxis, 2016.

25 SANTOS, Boaventura de Sousa. Os perigos da desordem jurídica no Brasil. In. PRONER, Carol; CITTADINO, Gisele; TENENBAUM, Marcio; RAMOS FILHO, Wilson. A resistência ao golpe de 2016. São Paulo: Projeto Editorial Praxis, 2016, p. 132.

26 SANTOS, Boaventura de Sousa. Os perigos da desordem jurídica no Brasil. In. PRONER, Carol; CITTADINO, Gisele; TENENBAUM, Marcio; RAMOS FILHO, Wilson. A resistência ao golpe de 2016. São Paulo: Projeto Editorial Praxis, 2016, p. 132.

${ }^{27}$ HERRERA FLORES, Joaquín. De habitaciones propias y otros espacios negados: una teoría crítica de las opresiones patriarcales. Bilbao: Instituto de Derechos Humanos Universidad de Deusto, 2005, p. 31-32. 
ULTRALIBERALISMO, EVANGELICALISMO POLÍTICO E MISOGINIA: A FORÇA TRIUNFANTE DO PATRIARCALISMO NA SOCIEDADE BRASILEIRA PÓS-IMPEACHMENT MAIQUEL ÂNGELO DEZORDI WERMUTH JOICE GRACIELE NIELSSON

sociedade a partir dos quais determinadas pessoas e grupos são rechaçados ou deslocados sistematicamente da participação plena na cultura, na economia e na política dominantes nessa sociedade em um dado momento histórico.

Em termos axiológicos, o patriarcalismo promove a naturalização de valores masculinos e femininos, como polos estanques e exclusivos da constituição humana, induzindo a uma construção social de direito e da política que divida no nível visível, a chamada esfera dos iguais perante a lei ${ }^{28}$; e outro invisível, aquela dos e das diferentes. ${ }^{29}$ Apesar do enorme avanço percorrido no que diz respeito à igualdade de tratamento, as antigas desigualdades se perpetuam ou se (re)inventam na medida em que se derrubam as fronteiras, ou seja, na medida em que as inegáveis conquistas jurídicas em termos de igualdade vão se diluindo pela aspiração de novas circunstâncias e contextos, de modo que a justiça para as mulheres "segue sendo um objetivo a alcançar, e é improvável que se consiga através da igualdade formal [...]. Na atualidade, a subordinação legal tem sido praticamente abolida e muitas pessoas questionam tais pressupostos, mas as estruturas sociais que neles se baseiam seguem vigentes" 30 .

Isto porque, a partir do patriarcalismo, é tido como inalterável todo um conjunto de leis, normas e valores, configurações institucionais e culturais que regem a vida das pessoas e dos povos sem admitir contestação, sem exegeses nem didáticas, pretendendo-se quase como revelação contra a qual não se pode conspirar, sob pena de converter-se em um marginal, tal qual os transexuais, intersexos e homossexuais, estudados por Judith Butler ${ }^{31}$ em suas reflexões sobre a (in)adequação a um ideal normativo e a patologização. Para a autora, ${ }^{32}$ a tentativa de estipular conceitos universais a partir de identidades pré-definidas soa excludente e contraditória: “as categorias de identidade nunca são meramente descritivas, mas sempre normativas e como tal, exclusivistas".

Desse modo, a tentativa tradicional de constituir a identidade dos sujeitos a partir da descrição revela-se um ato de normatização, controlando, pela exclusão e pré-definição,

\footnotetext{
${ }^{28}$ Ferrajoli afirma que "la 'igualdad jurídica' es, entonces, un principio normativo sobre la forma universal de los derechos que se ha convenido sean fundamentales: del derecho a la vida a los derechos de libertad, de los derechos políticos a los sociales, hasta ese metaderecho que es el derecho a la igualdad, es decir, al tratamiento igual ante la ley”. FERRAJOLI, Luigi. Derechos y garantías. La ley del más débil. Tradução de P. A. Ibáñez e A. Greppi. Madrid: Trotta, 2001, p. 81.

${ }^{29}$ AMORÓS, Célia. Hacia uma crítica de la razón patriarcal. Barcelona: Anthropos, 1997.

30 OKIN, Susan. Liberalismo político, justicia y género. In: CASTELLS, C. (Org.). Perspectivas feministas en teoría política. Barcelona: Paidós, 1996, p 146.

31 BUTLER, Judith. Problemas de Gênero: Feminismo e subversão da identidade. 3. ed. Rio de Janeiro: Civilização Brasileira, 2010.

32 BUTLER, Judith. Fundamentos contingentes: o feminismo e a questão do "pós-modernismo". Cadernos Pagu, n. 11, vol. 11-42, 1998, p. 36.
} 
ULTRALIBERALISMO, EVANGELICALISMO POLÍTICO E MISOGINIA: A FORÇA TRIUNFANTE DO PATRIARCALISMO NA SOCIEDADE BRASILEIRA PÓS-IMPEACHMENT MAIQUEL ÂNGELO DEZORDI WERMUTH JOICE GRACIELE NIELSSON

comportamentos linguísticos e sociais em geral. O perigo na definição de critérios a priori de humanidade está no seu oposto, ou seja, na produção do menos "humano", do inumano, do abjeto, justamente aqueles a quem a autora ${ }^{33}$ quer dar conta, concedendo humanidade ao inabitável, ao "invivível”, ao Outro que virou "merda".

É nesse sentido que fala de corpos que importam, e ao contrário, dos que não importam, considerados abjetos pela norma, desconstituídos de humanidade, e invisíveis, voltando-se à tentativa ética de desvincular do caráter patológico aqueles que apresentam complexidades não absorvidas pelo ideal normativo para, a partir da desmistificação das configurações sociais excludentes, devolver-lhes o direito básico a uma existência legítima. ${ }^{34}$ Segundo Butler, ${ }^{35}$ "o abjeto [...] não se restringe de modo algum a sexo e heteronormatividade", mas se relaciona "a todo tipo de corpos cujas vidas não são consideradas 'vidas' e cuja materialidade é entendida como não importante".

Portanto, qualquer variação das proposições dadas pelo sistema patriarcalista colocará os sujeitos dissidentes na marginalidade, tendo à sua disposição os mais diversos estigmas relacionados às sexualidades e às expressões de gênero, que se intensificam mais ainda quando se compõem com outras categorias, como classe social, raça e etnia, geração, enfim, com a violência estrutural. Obviamente, se a dimensão axiológica é importante, não pode ser absolutizada, pois este processo, como vimos, é multidimensional, e precisa ser compreendido, especialmente ao lado das dimensões econômica e política.

Adaptado à teoria fraseriana, poderíamos afirmar que o patriarcalismo atua simultaneamente na perspectiva: a) da distribuição, na medida em que as injustiças de gênero estão atreladas à diferenciação de classe e às estruturas econômicas, que mediante a divisão sexual do trabalho, distingue trabalho "produtivo" do "reprodutivo e doméstico", separando o trabalho bem pago e profissionalizado - dominado pelos homens - do mal pago ou não pago dominado pelas mulheres; b) do reconhecimento, na medida em que as injustiças de gênero estão relacionadas ao androcentrismo social, de modo que os padrões institucionalizados de valores culturais privilegiam características associadas à masculinidade e desvalorizam códigos de conduta "femininos", expressos em áreas como o direito, as políticas públicas e práticas profissionais. Por conta de tais padrões, as mulheres sofrem diversos tipos de subordinação, assédio, abuso sexual, violência, objetificação, representações estereotipadas e degradantes na

\footnotetext{
${ }^{33}$ BUTLER, Judith. Vida Precária: el poder del duelo y la violencia. Buenos Aires: Paidós, 2009.

${ }^{34}$ BUTLER, Judith. Cuerpos que importan: sobre los límites materiales y discursivos del "sexo". 1. ed. Buenos Aires: Paidós, 2002.

35 BUTLER, Judith. Cuerpos que importan: sobre los límites materiales y discursivos del "sexo". 1. ed. Buenos Aires: Paidós, 2002, p. 162.
} 
ULTRALIBERALISMO, EVANGELICALISMO POLÍTICO E MISOGINIA: A FORÇA TRIUNFANTE DO PATRIARCALISMO NA SOCIEDADE BRASILEIRA PÓS-IMPEACHMENT MAIQUEL ÂNGELO DEZORDI WERMUTH JOICE GRACIELE NIELSSON

mídia, marginalização das esferas públicas e negação de direitos ${ }^{36}$; e c) da representação, na medida em que as injustiças de gênero se relacionam à sub-representação política, ou seja, o não assegurar voz política igual a mulheres e grupos minoritários em comunidades políticas já constituídas.

Compreender nosso predador em todas estas dimensões que sustentam seu poder, seja política, axiológica e social, como o faz Herrera Flores ${ }^{37}$, ou nas dimensões econômica, cultural e política, como o faz Nancy Fraser ${ }^{38}$, nos permite realizar uma observação mais ampla dos fenômenos sociais de nosso tempo, e, mais do que isso, fazer frente a eles. Isso pressupõe compreender o vínculo permanente existente entre patriarcado e capitalismo, enquanto pilares de sustentação das formas de poder que hierarquizam e oprimem seres humanos a partir de diferenças biológicas ou morais. Uma espécie de patriarcado capitalista e ultraliberal, classista, racial, étnica e sexualmente estruturado, que entrelaça os problemas de gênero aos raciais, sexuais, étnicos e de classe social, e que de modo nenhum pode ser definido como homogêneo, e nem compreendido de forma unidimensional.

Seria, portanto, uma tradição política, axiológica e sociológica na qual um poder aumenta em relação direta com o outro poder, uma hierarquia superior se constitui a partir da subordinação hierárquica e os valores se conformam como universais a partir da desvalorização. Em nosso caso, um poder masculino, heterossexual, branco e capitalista, que se sustenta a partir de alguns princípios básicos elencados por Herrera Flores ${ }^{39}$ : o princípio da dominação nasce de diferenciações discriminatórias entre mulheres e homens, entre trabalhadores e capital, entre imigrantes e cidadãos, dentre várias outras, de modo que um não reconhece o outro, o exclui, o nomeia como inferior tornando-o invisível, anulando e o escravizando.

Este princípio constitui uma realidade muito antiga que encontra sua raiz na biologia, na política e na ética aristotélica. Através da dominação, as experiências dominantes são tidas como experiências universais, e o masculino se transforma em uma abstração universal, enquanto aquilo que representa a natureza e o feminino é somente um mero ponto de vista carregado de particularismos e vinculações naturalistas.

\footnotetext{
${ }^{36}$ FRASER, Nancy. Fortunas del feminismo. Traficantes de Sueños: Madrid, 2015.

${ }^{37}$ HERRERA FLORES, Joaquín. De habitaciones propias y otros espacios negados: una teoría crítica de las opresiones patriarcales. Bilbao: Instituto de Derechos Humanos Universidad de Deusto, 2005.

${ }^{38}$ FRASER, Nancy. O feminismo, o capitalismo e a astúcia da história. Mediações, v. 14, n. 2, p. 11-33, Londrina,jul./dez. 2009.

${ }^{39}$ HERRERA FLORES, Joaquín. De habitaciones propias y otros espacios negados: una teoría crítica de las opresiones patriarcales. Bilbao: Instituto de Derechos Humanos Universidad de Deusto, 2005, p. 34-35.
} 
ULTRALIBERALISMO, EVANGELICALISMO POLÍTICO E MISOGINIA: A FORÇA TRIUNFANTE DO PATRIARCALISMO NA SOCIEDADE BRASILEIRA PÓS-IMPEACHMENT MAIQUEL ÂNGELO DEZORDI WERMUTH JOICE GRACIELE NIELSSON

O princípio da complementariedade leva o dominado a aceitar sua situação de inferioridade, reforçando sua identidade através do sentimento inevitável de pertencimento a algo ou a alguém. Esta identificação faz com que os grupos oprimidos careçam de uma interpretação própria de sua opressão. Já o terceiro princípio, da necessidade é esclarecido por Célia Amorós ${ }^{40}$, para quem as mulheres, os indígenas, os negros, LGBTs, ao verem-se como um grupo inferior, aceitam ser esta a sua natureza, o que os impede de articular pontos de vista próprios, e consequentemente, abordar alternativas que se libertem dos princípios anteriores. Sob o capitalismo, o patriarcado está estruturado de modo que o sexismo restringe o comportamento das mulheres em alguns campos, enquanto em outras esferas thes permita uma liberação desta limitação, e a ausência de elaboração sobre esta condição leva muitas mulheres a ignorar as esferas nas quais são exploradas ou sofrem discriminação.

Por fim, o princípio da vitimização surge como consequência dos três princípios anteriores, fazendo com que os coletivos submetidos à lógica do patriarcado se percebem estaticamente como pobres, cidadãos de segunda classe, ou sujeitos estigmatizados pelo simples fato de pertencerem a grupos política, axiológica e sociologicamente inferiorizados. Deste modo, o patriarcalismo lhes faz assumir a qualificação de vítimas, ou seja, de sujeitos passivos destinados a sofrer irremediavelmente as consequências negativas do sistema. No entanto, sentir-se vítima não é o mesmo que se ver como exploradas, uma vez que esta, longe de ser uma categoria ontológica inamovível, é consequência de uma relação social concreta, determinada pelo modo em que se elaboram, se percebem e se enfrentam - política, axiológica e socialmente - as diferenças e as desigualdades.

A partir desta lógica, nosso predador patriarcalista contamina os processos de aprendizagem e constrói o que Rita Segato ${ }^{41}$ denomina de uma pedagogia da crueldade, que considera óbvio ou natural que determinadas pessoas ocupem lugares determinados e não possam figurar em outros. Conforme definem Gruba e Aquino, ${ }^{42}$ "esse argumento refere-se a um sistema que impõe como modelo a ideia de masculino, branco, proprietário e cidadão. Excluemse todos os demais humanos pondo-os em situação marginal, ou seja, fora desses padrões econômicos, não há qualquer condição de empoderamento". Está esse argumento, também, por trás do ódio à democracia revelado por Rancière, ${ }^{43}$ na medida em que ela representa justamente

\footnotetext{
${ }^{40}$ AMORÓS, Célia. Hacia uma crítica de la razón patriarcal. Barcelona: Anthropos, 1997.

${ }^{41}$ SEGATO, Rita Laura. La guerra contra las mujeres. Madrid: Traficantes de Sueños, 2016.

42 GRUBBA, Leilane Serratine; AQUINO, Sérgio Fernandes. O individualismo e patriarcalismo dos direitos humanos como marco da ideologia-mundo. Revista do Programa de Pós-Graduação em Direito da UFC, v. 36, n. 2, jul./dez. 2016, p. 197.

${ }^{43}$ RANCIĖRE, Jacques. O ódio à democracia. São Paulo: Boitempo, 2014, p. 63.
} 
"o poder próprio daqueles que não têm mais título para governar do que para ser governados", afinal de contas, “a democracia não é nem uma sociedade a governar nem um governo da sociedade, mas é propriamente esse ingovernável sobre o qual todo o governo deve, em última análise, descobrir-se fundamentado".

Importa destacar que, embora diante de uma pluralidade de enfoques e uma diversidade de atores e fatos, em alguns casos aparentemente muito distantes entre si, tais diferenças não podem ser consideradas incomensuráveis, já que compartilham em maior ou menor grau o objeto que enfrentam: o patriarcalismo como sistema de relações dominantes, capitalistas, que coloca apenas um ponto de vista, o masculino, branco, proprietário e cidadão como o padrão universal. Os reflexos desse modelo no processo de impeachment da Presidenta Dilma Rousseff serão analisados na sequência.

\section{PATRIARCALISMO, A MISOGINIA E O IMPEACHMENT DE 2016: “TCHAU QUERIDA"(?!)}

Delimitado o patriarcalismo como matriz de análise de nosso tempo, este tópico pretende explicitar de que modo este predador esteve presente na configuração dos acontecimentos político-jurídicos relativos ao processo de impedimento sofrido pela presidenta Dilma Rousseff, em 2016. Dessa forma, "poder-se-á entender como o poder patriarcal influi diretamente nas decisões políticas do país, fazendo com que violências de gênero e preconceitos sexistas acarretem em graves consequências não apenas para a mulher, mas para a sociedade como um todo" 44 .

Sustenta-se no presente artigo que o patriarcalismo, representado por uma aliança entre patriarcado e capitalismo como matriz de discriminação e diferenciação dos seres humanos em funções de diferenças biológicas, morais e econômicas, foi o grande motivador, impulsionador e agente deste processo. 0 que adveio daí foi uma espécie de processo de regressão civilizatória que, de forma violenta, busca articular "as forças sociais neoliberais, neoconservadores,

44 SALIBA, Maurício Gonçalves; SANTIAGO, Brunna Rabelo. Bailarinas não fazem política? Análise da violência de gênero presente no processo de impeachment de Dilma Rousseff. Revista Direitos Fundamentais e Democracia, v. 21, n. 21, p. 91-105, dez. 2016, p. 93. 
ULTRALIBERALISMO, EVANGELICALISMO POLÍTICO E MISOGINIA: A FORÇA TRIUNFANTE DO PATRIARCALISMO NA SOCIEDADE BRASILEIRA PÓS-IMPEACHMENT MAIQUEL ÂNGELO DEZORDI WERMUTH JOICE GRACIELE NIELSSON

conservadores, religiosos, autoritários e populistas" ${ }^{45}$, em suma, aqueles que sempre constituíram os grupos dos detentores do poder no Brasil.

Este processo não remonta apenas ao início do processo de impedimento propriamente dito, mas, especialmente, à eleição de 2015. O que se verificou a partir daquele momento no Brasil foi uma profunda aliança promovida por forças conservadoras associadas a um patriarcado institucionalizado e ao ultraliberalismo, entre fundamentalistas cristãos e conservadores em geral, que tomou conta do país, promovendo a hegemonia dos padrões androcêntricos e heteronormativos, e elegendo o Congresso mais conservador da história, colocando em marcha, “o 'avanço' da 'vanguarda do atraso' composta, fundamentalmente, pela chamada bancada BBB: bíblia (pastores fundamentalistas), boi (agronegócio) e bala (ligada diretamente à polícia e às empresas de segurança, ao aparato repressivo e contra o estatuto do desarmamento)" ${ }^{46}$, movimento que teve seu ápice com a eleição de Eduardo Cunha ${ }^{47}$ à presidência da Câmara dos Deputados.

No caso dos movimentos feministas, à luz das reflexões fraserianas, podemos dizer que, imersas no debate fragmentado das questões de gênero, e das disputas e exclusões internas, o feminismo, juntamente com outros movimentos progressistas, perdeu grande parte de sua capacidade de intervir e transformar a realidade. 0 debate empreendido no campo cultural tem prevalecido, camuflando questões distributivas que se acentuaram com a implantação perversa de desmonte dos direitos e proteções sociais conquistados a duras penas.

Este processo está, em grande medida, centrado no mote da "defesa dos valores familiares" e da "sociedade brasileira dos homens de bem" os quais, aliados a uma profunda misoginia não disfarçada, foram também os grandes motivadores do processo de impedimento aqui analisado. Nesse caso, a estratégia vencedora invocou uma política codificada de

\footnotetext{
45 SILVA, Maurício Roberto da; PIRES, Giovani de Lorenzi; PEREIRA, Rogérios Santos. O Congresso Nacional, a mídia e as questões de gênero no limiar da "primavera das mulheres". Motrivivência, v. 27, n. 46, p. 614, Florianópolis, dez. 2015, p. 22.

${ }^{46}$ FELIPPE, Igor. Um horizonte sombrio com o conservadorismo do Congresso: redução da maioridade é o $1^{\circ}$ ato. 2015. Disponível em: <http://cartamaior.com.br/?/Editoria/Politica/Um-horizonte-sombrio-como-conservadorismo-do-Congressoreducao-da-maioridade-e-o-1\%25BA-ato/4/33146>. Acesso em: 06 abr. 2017.

${ }^{47}$ Nunca houve, por parte de Cunha qualquer interesse em omitir ou esconder suas opiniões a respeito dos direitos das mulheres, despersonalizando, conforme exposto no trecho transcrito, o outro, neste caso, a mulher, da característica de humano. Confirma-se o fato a partir de atitudes do deputado, como por exemplo, a propositura do projeto de lei 5069/20133, o qual, em resumo, dificultava a realização do aborto em mulheres vítimas de estupro. Tal projeto adicionava procedimentos burocráticos como o registro de boletim de ocorrência e exame de corpo e delito para ensejar a autorização do aborto em gravidez oriunda de violência sexual. Além disso, propunha o aumento das penas para o ‘crime' de aborto.
} 
ULTRALIBERALISMO, EVANGELICALISMO POLÍTICO E MISOGINIA: A FORÇA TRIUNFANTE DO PATRIARCALISMO NA SOCIEDADE BRASILEIRA PÓS-IMPEACHMENT MAIQUEL ÂNGELO DEZORDI WERMUTH JOICE GRACIELE NIELSSON

reconhecimento de gênero para esconder uma política de redistribuição regressiva que estava em curso, sem que as pessoas a reconhecessem. ${ }^{48}$

Conforme aduz Marcia Tiburi, ${ }^{49}$ "todo governo tem seu inimigo e se deve levá-lo a sério. A direita combate a esquerda, e vice versa. Os capitalistas sempre combateram os comunistas e vice versa. Um governo autoritário combate a democracia de todos os modos". O governo Dilma, afirma a autora, teve como um dos seus principais inimigos o patriarcalismo, tendo na misoginia a personificação de seu discurso de ódio que ultrapassa comportamentos machistas cotidianos, chegando ao ponto de extirpar do poder uma mulher eleita democraticamente. Afinal, para a sociedade patriarcal, a política representa um campo masculino, no qual mulheres jamais serão bem-vindas.

Aliado ao patriarcalismo, outro inimigo, não menos importante, se faz presente: o ultraliberalismo, tal qual definido por Tzvetan Todorov. ${ }^{50}$ Para o autor, o ultraliberalismo, aliado ao messianismo e ao populismo, constituem uma tríade corrosiva dos fundamentos da promessa democrática, de modo que os princípios essenciais do discurso democrático se transformam em ameaças concretas.

A misoginia, ${ }^{51}$ por sua vez, esteve presente tanto na tentativa de diminuição pessoal de Dilma como ser humano, por meio de campanhas midiáticas que questionavam sua sexualidade ou intentavam oprimi-la pela sua condição de mulher, quanto, de forma mais ampla, como estratégia patriarcalista de atuações que "ocorreram com o intuito de impedir que Dilma exercesse a posição que the foi conferida democraticamente, qual seja, a de chefe de Estado, representam também uma forma de misoginia” ${ }^{2}$. Um exemplo clássico deste processo pode ser

48 FRASER, Nancy. Mapeando a imaginação feminista: da redistribuição ao reconhecimento e à representação. Estudos Feministas, v. 15, n. 2, p. 240, Florianópolis, maio/ago. 2007, p. 299.

49 TIBURI, Márcia. A Máquina Misógina e o Fator Dilma Rousseff na Política Brasileira. Revista Cult, 2016. Disponível em: < http://revistacult.uol.com.br/home/2016/07/a-maquina-misogina-e-o-fator-dilmarousseff-na-politica-brasileira/ >. Acesso em: 10 abr. 2017.

${ }^{50}$ TODOROV, Tzvetan. Os inimigos íntimos da democracia. Tradução de Joana Angélica d'Avila Melo. São Paulo: Companhia das Letras, 2012.

51 Sobre a misoginia, pode-se compreendê-la como, "o discurso de ódio contra as mulheres, um discurso que faz parte da história do patriarcado, do sistema da dominação e dos privilégios masculinos, daquilo que podemos chamar de machismo estrutural, o machismo que petrifica a sociedade em sua base e impede transformações democráticas. Quero dizer com isso que a luta pela democracia hoje se confunde com a luta contra a misoginia e todos os ódios a ela associados no espectro amplo do ódio à diferença". TIBURI, Márcia. A Máquina Misógina e o Fator Dilma Rousseff na Política Brasileira. Revista Cult, 2016. Disponível em: < http://revistacult.uol.com.br/home/2016/07/a-maquina-misogina-e-o-fator-dilmarousseff-na-politica-brasileira/ >. Acesso em: 10 abr. 2017.

52 SALIBA, Maurício Gonçalves; SANTIAGO, Brunna Rabelo. Bailarinas não fazem política? Análise da violência de gênero presente no processo de impeachment de Dilma Rousseff. Revista Direitos Fundamentais e Democracia, v. 21, n. 21, p. 91-105, dez. 2016, p. 97. 
ULTRALIBERALISMO, EVANGELICALISMO POLÍTICO E MISOGINIA: A FORÇA TRIUNFANTE DO PATRIARCALISMO NA SOCIEDADE BRASILEIRA PÓS-IMPEACHMENT MAIQUEL ÂNGELO DEZORDI WERMUTH JOICE GRACIELE NIELSSON

encontrado no slogan "tchau querida", utilizado de maneira massiva em charges e outros suportes, de forma "irônica e debochada"53.

Sobre o tema, Flávia Biroli ${ }^{44}$, destaca uma charge "que é Dilma saindo do Palácio do Planalto e andando em direção ao Palácio da Alvorada, nua, com a marca de um chute nas nádegas acompanhada dos dizeres 'Tchau, querida'”. Para além das formulações das charges e das reportagens, as próprias imagens, as próprias fotografias do processo de impeachment, mostravam a composição masculina do Congresso Nacional a olho nu e a ironia marcada no "Tchau, querida" como uma forma de expressar o que seria um modo coloquial de tratamento entre mulheres colocado contra uma mulher quando ela se desloca do espaço das relações cotidianas e assume uma centralidade na política. ${ }^{55}$

Outra forte aliada da perpetuação desta violência patriarcalista foi, de acordo com Saliba e Santiago ${ }^{56}$, a mídia. Os meios de comunicação não pouparam ofensas machistas e de teor sexual em relação à presidenta, utilizando, assim, uma violência de gênero para contribuir com a retirada de Dilma do poder. Os autores ${ }^{57}$ destacam especialmente a edição da revista “Isto É!", que, na capa, ilustrava a imagem do rosto da presidenta distorcido, demonstrando, assim, a violência moral, estética e simbólica, já tão naturalizada nas relações sociais, atribuindo "a Dilma surtos e desequilíbrios emocionais e psiquiátricos nas vésperas da votação do impeachment" ${ }^{28}$.

Muitas campanhas midiáticas utilizaram também "adesivos de cunho sexual contra a governanta", afirma a autora. ${ }^{59}$ Um exemplo concreto é um adesivo de carro que reproduzia a violência sexual, o estupro, mostrando Dilma de pernas abertas sobre o tanque de gasolina do carro. Exemplos como estes, que fazem uso de distorções de cunho patriarcal, se tornaram prática rotineira por aqueles que interpretam a política como um jogo sem regras,

53 BOITEUX, Luciana. Misoginia no golpe. In: PRONER, Carol. [et. al.] (orgs). A Resistência ao Golpe de 2016. Bauru: Canal 6, p. 261-266, 2016, p. 264.

${ }^{54}$ BIROLLI, Flávia. GERALDES, Elen Cristina [et. al] (Orgs). Mídia, misoginia e golpe. Brasília: FAC-UnB, 2016, p. 103.

${ }_{55}$ BIROLLI, Flávia. GERALDES, Elen Cristina [et. al] (Orgs). Mídia, misoginia e golpe. 1. ed. Brasília: FAC UnB, 2016.

56 SALIBA, Maurício Gonçalves; SANTIAGO, Brunna Rabelo. Bailarinas não fazem política? Análise da violência de gênero presente no processo de impeachment de Dilma Rousseff. Revista Direitos Fundamentais e Democracia, v. 21, n. 21, p. 91-105, dez. 2016.

57 SALIBA, Maurício Gonçalves; SANTIAGO, Brunna Rabelo. Bailarinas não fazem política? Análise da violência de gênero presente no processo de impeachment de Dilma Rousseff. Revista Direitos Fundamentais e Democracia, v. 21, n. 21, p. 91-105, dez. 2016.

58 BOITEUX, Luciana. Misoginia no golpe. In: PRONER, Carol. [et. al.] (orgs). A Resistência ao Golpe de 2016. Bauru: Canal 6, p. 261-266, 2016, p. 261.

59 BOITEUX, Luciana. Misoginia no golpe. In: PRONER, Carol. [et. al.] (orgs). A Resistência ao Golpe de 2016. Bauru: Canal 6, p. 261-266, 2016, p. 264. 
ULTRALIBERALISMO, EVANGELICALISMO POLÍTICO E MISOGINIA: A FORÇA TRIUNFANTE DO PATRIARCALISMO NA SOCIEDADE BRASILEIRA PÓS-IMPEACHMENT MAIQUEL ÂNGELO DEZORDI WERMUTH JOICE GRACIELE NIELSSON

representando, ainda, o claro desespero do mercado comum à imprensa ${ }^{60}$. Não se pode olvidar, neste ponto, do fato de que a mídia de massas, no Brasil, se configura como "a força política mais articulada e influente em nosso país", e apresenta como principais características uma propriedade altamente concentrada e uma estreita relação com a última ditadura estabelecida, “à sombra da qual expandiu enormemente seus negócios"61.

Neste sentido, afirma Flávia Biroli62 que, embora o sexismo se perpetue ao longo do tempo, havia uma percepção de que os discursos misóginos - "que anulam as mulheres como sujeitas igualmente competentes na política" - vinham se enfraquecendo ao longo do tempo, especialmente, na mídia. No entanto, as narrativas enunciadas durante o impeachment evidenciaram que os discursos misóginos não estavam, de maneira alguma, neutralizados.

“Houve várias reportagens na qual a presidenta Dilma Rousseff foi caracterizada de acordo com os estereótipos mais convencionais de gênero, aqueles que recusam a condição de atrizes políticas às mulheres" (idem), dos quais são exemplos os discursos sobre a incapacidade das mulheres terem equilíbrio ao tomar decisões; incapacidade de reagirem de maneira racional às pressões; incapacidade de liderança porque estariam sempre atreladas a projetos de outros atores políticos homens. Tudo isso "permeou, imagética e discursivamente, o que esteve presente na construção desse ambiente político"63.

Por tudo isso, Dilma Rousseff foi atacada como mulher por diferentes atores políticos que compuseram o espectro patriarcalista do processo, todos, utilizando-se de uma retórica com aspectos de gênero e misoginia que contribuíram sobremaneira para a construção de um enquadramento que definia caminhos específicos para a solução da crise, e ao mesmo tempo definia Dilma Rousseff como incapaz de trilhar esses caminhos, especialmente dada sua condição de mulher.

Criou-se um cenário de crise, no qual despontavam apenas uma solução e alguns agentes competentes para executá-la. Segundo o discurso patriarcalista, "Dilma - enquanto mulher, petista - não seria capaz de liderar esse processo, e, portanto, dele foi excluída, sem que houvesse, de fato, uma discussão sobre no que esses caminhos implicavam em termos de projeto

60 TIBURI, Márcia. Dilma, Janaína e "Gaslighting". Revista Cult, 2016. Disponível em: < http://revistacult.uol.com.br/home/2016/04/dilma-janaina-e-gaslighting/ >. Acesso em: 10 abr. 2017.

${ }^{61}$ SILVA, Adriano Correia. Um fascismo liberal exótico e a nostalgia do Brasil Colônia. Revista do Instituto Humanitas UNISINOS, $n^{\circ} 490$, ano XVI, p. 54-59, ago. 2016, p. 56.

${ }^{62}$ BIROLLI, Flávia. GERALDES, Elen Cristina [et. al] (Orgs). Mídia, misoginia e golpe. Brasília: FAC-UnB, 2016, p. 130.

${ }^{63}$ BIROLLI, Flávia. GERALDES, Elen Cristina [et. al] (Orgs). Mídia, misoginia e golpe. Brasília: FAC-UnB, 2016, p. 130. 
ULTRALIBERALISMO, EVANGELICALISMO POLÍTICO E MISOGINIA: A FORÇA TRIUNFANTE DO PATRIARCALISMO NA SOCIEDADE BRASILEIRA PÓS-IMPEACHMENT MAIQUEL ÂNGELO DEZORDI WERMUTH JOICE GRACIELE NIELSSON

para o Brasil", que nada mais seria do que uma virada ultraliberal na condução das políticas públicas. $^{64}$

Apesar da distância em relação à realidade, essa retórica codificada de gênero se mostrou imensamente poderosa - tanto para eleitores quanto para eleitoras. Tão poderosa, na verdade, que pareceu, e ainda parece, neutralizar, os chamados pontos fracos do governo que estava assumindo: sua política conservadora de redistribuição, que está trazendo, e trará mais ainda significativas dificuldades para muitos brasileiros. O efeito foi colocar a política de redistribuição de ponta cabeça, promovendo injustiça social, o que de fato parece não importar à grande massa da população, envolta nos discursos de ódio acima identificados. Assim, uma política de gênero codificada efetivamente se sobrepôs a uma política de redistribuição regressiva.

Uma dinâmica similar, e que também ressalta a investida patriarcal aqui investigada, assenta-se no uso estratégico da retórica dos “valores familiares", agregando, assim, mais um dos pilares de sustentação ao patriarcado ao processo: o fundamentalismo religioso. 0 fenômeno traz à tona uma ideologia rasa que se manifesta nas ruas, nas famílias, nos espaços escolares, nas igrejas, nos órgãos governamentais, enfim, nas instituições de modo geral, pregando em nome de um neopentecostalismo a "defesa da família, da moral e dos bons costumes”

Esta estratégia fica evidente, a partir de uma análise dos discursos empreendidos por muitos deputados federais no momento de "justificar" o voto pelo prosseguimento, no Senado, do processo de impeachment da presidenta Dilma Rousseff, no dia 17 de abril de $2016 .{ }^{66}$ Neles, as palavras deus e minha família constituíram um argumento contumaz: a Deputada Mara Gabrilli (PSDBSP) votou "pelo fim dessa quadrilha que assaltou o país, pelo meu pai que tanto sofreu na mão do PT, pelo meu povo brasileiro, eu voto sim". ${ }^{67}$

Já o Deputado Fabio Sousa (PSDB-GO) afirmou: “Pela minha família! Meus filhos Estevão, Amanda, pela minha esposa, pelos meus pais, pelo meu estado de Goiás, pelo futuro do Brasil, eu

${ }^{64}$ BIROLLI, Flávia. GERALDES, Elen Cristina [et. al] (Orgs). Mídia, misoginia e golpe. Brasília: FAC-UnB, 2016, p. 131.

65 SILVA, Maurício Roberto da; PIRES, Giovani de Lorenzi; PEREIRA, Rogérios Santos. O Congresso Nacional, a mídia e as questões de gênero no limiar da "primavera das mulheres". Motrivivência, v. 27, n. 46, p. 6 14, Florianópolis, dez. 2015, p. 22.

66 Para uma análise aprofundada dos referidos discursos na deflagração do processo de impedimento, consultar WERMUTH, Maiquel Ângelo Dezordi; NIELSSON, Joice Graciele. "Pela minha família, por deus e pelo fim da corrupção": notas sobre o patrimonialismo na política brasileira contemporânea e a falência do Estado Democrático de Direito. Revista Direitos Fundamentais e Democracia, v. 22, n. 1, p. 46-79, jan./abr. 2017. Disponível em: < http://revistaeletronicardfd.unibrasil.com.br/index.php/rdfd/article/ view/870/498 >. Acesso em: 25 abr. 2017.

67 Vídeo com o voto da Parlamentar pode ser encontrado em: < https://www.youtube.com/ watch?v=lljPBZaqXtc >. Acesso em: 10 abril 2017. 
ULTRALIBERALISMO, EVANGELICALISMO POLÍTICO E MISOGINIA: A FORÇA TRIUNFANTE DO PATRIARCALISMO NA SOCIEDADE BRASILEIRA PÓS-IMPEACHMENT MAIQUEL ÂNGELO DEZORDI WERMUTH JOICE GRACIELE NIELSSON

digo sim." ${ }^{68}$ [grifou-se]. O Deputado Marco Feliciano (PSC-SP), por sua vez, afirmou: "Com ajuda de Deus, pela minha família, pelos evangélicos da nação toda, pelos meninos do MBL, pelo Vem Pra Rua, dizendo que Olavo tem razão, dizendo tchau para essa querida, e dizendo tchau ao PT, partido das trevas, eu voto sim". ${ }^{69}$ [grifou-se].

Muitas falas repetiram este padrão, mas talvez nenhuma delas de maneira tão emblemática, quanto aquela proferida pelo Deputado Jair Bolsonaro: “Perderam em 1964, perderam em 2016. Contra o comunismo, contra o Foro de São Paulo. Pela memória do coronel Carlos Alberto Brilhante Ustra, que foi o pavor de Dilma Rousseff”. “Essa frase bem define o golpe de 2016: a declaração de Bolsonaro pelo impedimento se baseou em dois elementos: a apologia da tortura e de um torturador e a misoginia com que ele expressou seu repúdio à mulher"70. A fala demonstra, portanto, segundo Saliba e Santiago, ${ }^{71}$ que o parlamentar concorda com esses atos, diminuindo a mulher e a colocando em posição inferior a de ser humano, qual seja, de mero objeto sexual cuja função limita-se a satisfazer as necessidades do homem. ${ }^{72}$

É justamente na utilização da retórica de defesa dos valores familiares que jaz uma grande ironia patriarcalista, apontada por Nancy Fraser. $^{73}$ Segundo a autora, as verdadeiras tendências que estão tornando a vida em família tão difíceis para as classes média e trabalhadora derivam da agenda capitalista neoliberal aprofundada pelo governo pósimpedimento. Tais políticas, definidas por Tzvetan Todorov ${ }^{74}$ como ultraliberais, ou seja, uma forma mais radical, aprofundada e cruel de liberalismo econômico, incluem seguridade social e proteção ao consumidor reduzidas, baixos salários e emprego precário, diminuição ou praticamente anulação dos investimentos sociais, dentre outros.

68 Vídeo com o voto do Parlamentar pode ser encontrado em: < https: / /www.youtube.com/watch?v=H8aagZObsI0 >. Acesso em: 10 abril 2017.

69 Vídeo com o voto do Parlamentar pode ser buscado em: < https: / /www.youtube.com/watch?v=Gf7z3bNS_Gw >. Acesso em: 10 abril 2017.

70 BOITEUX, Luciana. Misoginia no golpe. In: PRONER, Carol. [et. al.] (orgs). A Resistência ao Golpe de 2016. Bauru: Canal 6, p. 261-266, 2016, p. 266.

71 SALIBA, Maurício Gonçalves; SANTIAGO, Brunna Rabelo. Bailarinas não fazem política? Análise da violência de gênero presente no processo de impeachment de Dilma Rousseff. Revista Direitos Fundamentais e Democracia, v. 21, n. 21, p. 91-105, dez. 2016.

72 Em uma espécie de "retrato falado" de Jair Bolsonaro, Dieguez, a partir de pesquisa realizada pelo Instituto Datafolha, destaca que "o militar reformado fala mais à imaginação dos homens: três de cada quatro eleitores seus são do sexo masculino. Além disso [...] ele se sai bem entre os jovens - 65\% dos que o apoiam têm entre 16 e 34 anos." DIEGUEZ, Consuelo. Direita, volver. Revista Piauí, ano 10, n. 120, set. 2016, p. 20.

${ }^{73}$ FRASER, Nancy. Fortunas del feminismo. Traficantes de Sueños: Madrid, 2015.

74 TODOROV, Tzvetan. Os inimigos íntimos da democracia. Tradução de Joana Angélica d'Avila Melo. São Paulo: Companhia das Letras, 2012. 
ULTRALIBERALISMO, EVANGELICALISMO POLÍTICO E MISOGINIA: A FORÇA TRIUNFANTE DO PATRIARCALISMO NA SOCIEDADE BRASILEIRA PÓS-IMPEACHMENT MAIQUEL ÂNGELO DEZORDI WERMUTH JOICE GRACIELE NIELSSON

“Graças a essas tendências conexas, não é mais possível sustentar a família com apenas um emprego, e muitas vezes nem mesmo com dois. Longe de ser voluntário ou suplementar, o salário da mulher torna-se obrigatório, um pilar indispensável da ordem econômica neoliberal"75. "Tais são as forças que estão realmente ameaçando a vida em família em nosso país"76.

Apesar das feministas e dos progressistas terem compreendido isso, não conseguiram convencer muitos dos que são prejudicados por essas políticas. Ao contrário, o patriarcalismo conseguiu persuadi-los de que são temas como o direito ao aborto, questões relativas ao casamento homoafetivo, a transexualidade, o feminismo, os direitos humanos, os presos, os imigrantes, etc., que ameaçam seu estilo de vida. Em outras palavras, aduz Fraser ${ }^{77}$ os conservadores ultraliberais "usaram de forma bem-sucedida a política anti-feminista de reconhecimento para esconder a política de redistribuição anti-classe trabalhadora" que está sendo implementada.

Exemplo disso pode ser evidenciado, novamente, na análise de alguns dos principais atos do governo brasileiro pós-impedimento: extinção da Secretaria de Política para Mulheres, da Secretaria da Igualdade Racial, e, especialmente do ponto de vista simbólico, a nomeação de um ministério composto por homens, brancos, e economicamente independentes. O retorno, simbólico, das mulheres a seu espaço privado, cumprindo o papel de serem "Belas, recatadas e do lar"78, e auxiliando no desenvolvimento da economia do país a partir do controle da alteração dos preços dos produtos domésticos dos supermercados, ${ }^{79}$ tudo isso sacramentado pela retirada da obrigatoriedade dos estudos em gênero da nova Base Nacional Comum Curricular. ${ }^{80}$ É, de fato, o patriarcalismo recolocando as coisas nos seus lugares naturais.

75 FRASER, Nancy. Mapeando a imaginação feminista: da redistribuição ao reconhecimento e à representação. Estudos Feministas, v. 15, n. 2, p. 240, Florianópolis, maio/ago. 2007, p. 301.

76 FRASER, Nancy. Mapeando a imaginação feminista: da redistribuição ao reconhecimento e à representação. Estudos Feministas, v. 15, n. 2, p. 240, Florianópolis, maio/ago. 2007, p. 32.

77 FRASER, Nancy. Mapeando a imaginação feminista: da redistribuição ao reconhecimento e à representação. Estudos Feministas, v. 15, n. 2, p. 240, Florianópolis, maio/ago. 2007, p. 300.

780 uso desta expressão remete ao título de uma reportagem publicada pela Revista VEJA no dia 18 de abril de 2016, fazendo referência ao modelo ideal representado pela agora primeira-dama Marcela Temer, definindo-a como "Bela, recatada e do lar". Disponível em: <http://veja.abril.com.br/brasil/marcelatemer-bela-recatada-e-do-lar/>. Acesso em: 16 abr. 2017.

${ }^{79} \mathrm{Em}$ uma referência à fala do Presidente Michel Temer realizada no dia 08 de março, na qual cita como grande contribuição das mulheres à economia do país, o controle da flutuação dos preços dos produtos domésticos realizada nos supermercados. Disponível em: <http://www2.planalto.gov.br/acompanheplanalto/discursos/discursos-do-presidente-da-republica/discurso-do-presidente-da-republica-michel-

temer-durante-cerimonia-de-comemoracao-pelo-dia-internacional-da-mulher-brasilia-df>. Acesso em: 16 abr. 2017.

${ }^{80}$ Disponível em: < http://basenacionalcomum.mec.gov.br >. Acesso em: 16 abr. 2017. 
ULTRALIBERALISMO, EVANGELICALISMO POLÍTICO E MISOGINIA: A FORÇA TRIUNFANTE DO PATRIARCALISMO NA SOCIEDADE BRASILEIRA PÓS-IMPEACHMENT MAIQUEL ÂNGELO DEZORDI WERMUTH JOICE GRACIELE NIELSSON

É neste ponto, também, que o já referido "fascismo social" ao qual se refere Boaventura de Sousa Santos ${ }^{81}$ é "complementado" por um outro tipo de fascismo, qual seja, "um fascismo difuso ou fragmentário que atua nos espaços-tempo que historicamente têm constituído o campo político da democracia, ou seja, os espaços-tempo da cidadania e da comunidade". Trata-se, aqui, de "um fascismo que opera nos interstícios da democracia", utilizando-se "de meios antidemocráticos de desestabilização política, hoje particularmente visível nos países onde as classes populares e os movimentos sociais obtiveram vitórias significativas por meio da democracia representativa, as quais lhes permitiram assumir o poder político do Estado".

Esse fascismo se revela sempre que "as classes dominantes não conseguem retomar rapidamente o controle do Estado via DR [democracia representativa]", recorrendo "a meios antidemocráticos para desestabilizar as democracias." Em síntese, evidencia-se aqui uma estratégia das classes hegemônicas de "colocar a democracia a seu serviço e inculcar a ideia de que a democracia, quando não a seu serviço, é ingovernável" ${ }^{82}$. Como assevera Teles ${ }^{83}$ "quando a democracia liberal entra em crise (como podemos ver no Brasil de 2016), o fascismo aciona as subjetivações conservadoras, que no país podemos localizar no machismo, nas fobias de gênero, em certa xenofobia, no preconceito contra os nordestinos, operários, militantes políticos etc."

No caso brasileiro, Silva ${ }^{84}$ salienta que as posições fascistas possuem um certo ar "exótico", na medida em que se identificam como "liberais", revelando uma espécie de nostalgia do período colonial e da sua rígida hierarquia social. Para o filósofo, a compreensão das posições extremas e próximas ao fascismo na contemporaneidade perpassa pela análise de algumas tímidas transformações no modo de vida da população mais pobre, como a elevação do salário mínimo, acesso ao ensino superior e direitos aos trabalhadores domésticos: "aí podemos talvez encontrar a base afetiva do ódio contra todo o sistema político capitaneado pela classe média sonegadora e batedora de panelas e justificado pelas razões mais várias". De acordo com a perspectiva de Teles ${ }^{85}$,

\footnotetext{
81 SANTOS, Boaventura de Sousa. A difícil democracia: reinventar as esquerdas. São Paulo: Boitempo, 2016.

82 SANTOS, Boaventura de Sousa. A difícil democracia: reinventar as esquerdas. São Paulo: Boitempo, 2016, p. 133-134.

83 TELES, Amelinha. In: GERALDES, Elen Cristina [et. al] (Orgs). Mídia, misoginia e golpe. Brasília: FACUnB, 2016, p. 61.

${ }^{84}$ SILVA, Adriano Correia. Um fascismo liberal exótico e a nostalgia do Brasil Colônia. Revista do Instituto Humanitas UNISINOS, $n^{\circ} 490$, ano XVI, p. 54-59, ago. 2016, p. 58.

85 TELES, Edson. Na dissimulação democrático-liberal, o fascismo apresenta suas armas. Revista do Instituto Humanitas UNISINOS, ${ }^{\circ}$ 490, ano XVI, p. 60-64, ago. 2016, p. 61.
} 
ULTRALIBERALISMO, EVANGELICALISMO POLÍTICO E MISOGINIA: A FORÇA TRIUNFANTE DO PATRIARCALISMO NA SOCIEDADE BRASILEIRA PÓS-IMPEACHMENT MAIQUEL ÂNGELO DEZORDI WERMUTH JOICE GRACIELE NIELSSON

no Brasil, a maior característica do fascismo é se travestir de democrático e liberal. Sob o discurso pacifista, legalista, nacionalista e do "bom" cidadão, as ações fascistas ocorrem pela violência contra o divergente, o "anormal", o "desqualificado", o "vândalo". De modo geral, utilizando-se das estruturas do Estado policial, em especial das instituições militares, mas também via judiciário, a repressão e a violação de direitos ocorrem sob a alegação de se fazer o que é possível na situação atual. Com isto se legitimam políticas públicas desrespeitosas, que promovem a desigualdade e aprofundam a injustiça social.

Tudo isso representa, nos termos deste artigo, a consolidação do avanço do patriarcalismo e sua (re)tomada do poder na sociedade brasileira, ancorado por uma profunda aliança entre ultraliberalismo econômico, fundamentalistas religiosos e conservadores de um modo geral, representada na configuração de um governo ${ }^{86}$ cujo poder é exercido por e para, homens, brancos, heterossexuais e economicamente ativos (ricos), enquanto as mulheres e outros grupos subalternos exercem seus papéis "naturais" e não remunerados de cuidado, no mundo privado. Em um contexto tal, Silva ${ }^{87}$ salienta que o fato de o atual governo ter retomado o lema "ordem e progresso" revela uma estratégia no sentido de "recolocar as coisas nos eixos de sempre", sendo que a perspectiva de "ordem e progresso" em mira ainda é aquela que guarda uma afetividade com as relações sociais definidas no Brasil Colônia.

Nesse cenário, merece reflexão a necessária visão multidimensional e não fragmentária na compreensão do patriarcalismo, proposta na parte inicial do artigo. Sem compreendermos a totalidade do fenômeno, progressistas brasileiros mudaram o foco da redistribuição para o reconhecimento no momento em que a direita aperfeiçoava seu próprio uso estratégico de uma política cultural regressiva para tirar a atenção de sua política de redistribuição regressiva. Foi uma coincidência infeliz. ${ }^{88} 0$ relativo desprezo à economia política do feminismo e de outros movimentos progressivos acabou jogando a favor da onda conservadora, que colheu os principais benefícios da virada cultural, como se verificou através do processo de impeachment, aqui analisado, criando as condições de possibilidade para a (re)tomada do poder pelo patriarcalismo.

\footnotetext{
${ }^{86}$ Quando falamos governo, não nos referimos especificamente ao Presidente atual Michel Temer, pois consideramos que o modelo patriarcalista que este representa se constitui para além da sua pessoa.

87 SILVA, Adriano Correia. Um fascismo liberal exótico e a nostalgia do Brasil Colônia. Revista do Instituto Humanitas UNISINOS, $n^{\circ} 490$, ano XVI, p. 54-59, ago. 2016, p. 57.

${ }^{88}$ FRASER, Nancy. Fortunas del feminismo. Traficantes de Sueños: Madrid, 2015.
} 


\section{O EVANGELICALISMO POLÍTICO E A SUSTENTAÇÃO ULTRALIBERAL DO PATRIARCALISMO}

Analisando os acontecimentos brasileiros da atualidade a partir da lógica do patriarcalismo, resta ainda um questionamento não menos importante para os termos deste estudo: como os brasileiros foram sugados e enganados por este processo? E por que tantas mulheres mostraram-se suscetíveis a esse apelo codificado de gênero? A resposta para tais questionamentos parece estar no aparelho de sustentação do patriarcado, constituído, especialmente, por um movimento denominado por Nancy Fraser ${ }^{89}$ de "evangelicalismo político", uma espécie de aliança entre ultraliberais e fundamentalistas religiosos, que se reforçam mutuamente a partir da emergência de um novo tipo de sociedade, a que Fraser ${ }^{90}$ chama de "sociedade da insegurança".

A sociedade da insegurança é a sucessora da "sociedade da seguridade" que estava associada à social-democracia do período anterior. Diferentemente desta, afirma Fraser, ${ }^{91}$ a nova sociedade institucionaliza uma crescente insegurança nas condições de vida da maioria das pessoas. Em grande medida estas institucionalizações se dão a partir da implantação de políticas ultraliberais que enfraquecem as proteções da seguridade social ao institucionalizar formas mais precárias de trabalho assalariado, incluindo terceirização, trabalho temporário e trabalho não sindicalizado, que são mal pagos e não dão direito a benefícios. Do mesmo modo, enfraquecem as garantias de aposentadoria, de acesso à saúde pública, bem como eliminam programas assistenciais e de redistribuição de renda. 0 resultado é uma grande sensação de insegurança, à qual o cristianismo evangélico responde.

No cenário brasileiro em análise, as hipóteses elencadas por Fraser se fazem plenamente verificáveis. As primeiras medidas adotadas pelo governo que assumiu em nome do patriarcalismo, após o processo de impeachment representaram uma virada ultraliberal na condução das políticas públicas, pautadas por uma retórica de crise financeira e fiscal do Estado, atribuída ao "imenso" custo dos direitos e garantias atribuídos aos cidadãos. De acordo com a leitura de Ramon Blanco92, essa virada ultraliberal na condução das políticas públicas

\footnotetext{
89 FRASER, Nancy. Mapeando a imaginação feminista: da redistribuição ao reconhecimento e à representação. Estudos Feministas, v. 15, n. 2, p. 240, Florianópolis, maio/ago. 2007.

90 FRASER, Nancy. Fortunas del feminismo. Traficantes de Sueños: Madrid, 2015, p. 303.

91 FRASER, Nancy. Fortunas del feminismo. Traficantes de Sueños: Madrid, 2015.

92 BLANCO, Ramon. A doutrina de choque temerária. Le Monde Diplomatique Brasil, ano $10, \mathrm{n}^{\circ} 116, \mathrm{p}$. 11, mar. 2017, p. 11.
} 
ULTRALIBERALISMO, EVANGELICALISMO POLÍTICO E MISOGINIA: A FORÇA TRIUNFANTE DO PATRIARCALISMO NA SOCIEDADE BRASILEIRA PÓS-IMPEACHMENT MAIQUEL ÂNGELO DEZORDI WERMUTH JOICE GRACIELE NiELSSON

pressupõe um processo de ruptura drástico que viabilize o ambiente propício para sua implementação: “é necessário um choque inicial, uma suspensão da normalidade política [...] para haver o ambiente adequado e propício ao avanço de tal agenda."

Isso porque é justamente a partir da exploração da instabilidade advinda deste choque inicial, "amparado no medo, na desorientação, na desarticulação política de oposicionistas, e assim por diante - que o choque neoliberal avança”. E a velocidade desse avanço, nessas circunstâncias, é ainda maior, sendo característica do processo a utilização de forças policiais para reprimir as manifestações contrárias, configurando uma verdadeira "doutrina do choque".

$\mathrm{Na}$ leitura de Boaventura de Sousa Santos, ${ }^{93}$

a hipertrofia dos mercados financeiros não permite crescimento económico e, pelo contrário, exige políticas de austeridade por via dos quais os pobres são investidos do dever de ajudar os ricos a manterem a sua riqueza e, se possível, a serem mais ricos. Nestas condições, as precárias classes médias criadas no período anterior ficam à beira do abismo de pobreza abrupta. Intoxicadas pela mídia conservadora, facilmente convertem os governos responsáveis pelo que são hoje em responsáveis pelo que lhes pode acontecer amanhã.

Obviamente este cenário não é apenas nacional, apresentando reflexos em toda a ordem mundial, como os efeitos mundiais desastrosos causados pela intenção de se estabelecer um único mercado, cuja insegurança estimula investimentos mais duradouros, como é o caso da força bélica de alguns territórios. ${ }^{94}$ Esse cenário causa profundas misérias humanas em decorrência desse estado perpétuo de conflito, como ilustra o número significativo de imigrantes e refugiados que circulam pelo globo, os quais deixam a sua terra natal devido à ausência de qualquer estabilidade cultural, política ou jurídica, conforme muito bem apreendido na obra de Bauman. ${ }^{95}$

Sobre esta política ultraliberal, Todorov ${ }^{96}$ já alertava que

os EUA encarnam uma forma ainda mais radical desse ultraliberalismo e, se nas próximas eleições americanas houver uma vitória do candidato republicano, temos um passo em direção a uma absorção quase definitiva do ingrediente social da organização pública e não sei se se pode falar de democracia neste caso

93 SANTOS, Boaventura de Sousa. Os perigos da desordem jurídica no Brasil. In. PRONER, Carol; CITTADINO, Gisele; TENENBAUM, Marcio; RAMOS FILHO, Wilson. A resistência ao golpe de 2016. São Paulo: Projeto Editorial Praxis, 2016, p. 65.

${ }^{94}$ GRUBBA, Leilane Serratine; AQUINO, Sérgio Fernandes. 0 individualismo e patriarcalismo dos direitos humanos como marco da ideologia-mundo. Revista do Programa de Pós-Graduação em Direito da UFC, v. 36, n. 2, jul./dez. 2016.

${ }_{95}$ BAUMAN, Zygmunt. Estranhos à nossa porta. Rio de Janeiro: Zahar, 2017.

${ }^{96}$ TODOROV, Tzvetan. Os inimigos íntimos da democracia. Tradução de Joana Angélica d'Avila Melo. São Paulo: Companhia das Letras, 2012, p. 58. 
ULTRALIBERALISMO, EVANGELICALISMO POLÍTICO E MISOGINIA: A FORÇA TRIUNFANTE DO PATRIARCALISMO NA SOCIEDADE BRASILEIRA PÓS-IMPEACHMENT MAIQUEL ÂNGELO DEZORDI WERMUTH JOICE GRACIELE NIELSSON

a destruição de todo o Estado de bem-estar social, de toda a social democracia, de toda a preocupação com o bem comum.

No Brasil, os reflexos desta guinada na condução das políticas públicas podem ser averiguados a partir de muitos eventos, podendo ser citados a título exemplificativo:

a) a aprovação da chamada Proposta de Emenda à Constituição n 55, de 2016 - PEC do teto dos gastos públicos (agora Emenda Constitucional n. 95 de 15/12/2016) ${ }^{97}$ que, na leitura de Rossi e Mello (2017, p. 7), representa “o fim do Estado garantidor de direitos, uma vez que a proposta impõe a diminuição do tamanho e do papel do Estado, impedindo o funcionamento dos serviços públicos e da rede de proteção social";

b) a aprovação, pela Câmara, em 21 de março de 2017 do Projeto de Lei (PL) 4.302, apresentado em 1998, que aprova a terceirização generalizada, em todas as atividades, inclusive na atividade-fim, e também altera regras para o trabalho temporário, tanto no setor privado quanto público. Esta proposta representa o maior retrocesso nas leis trabalhistas em décadas, numa clara sinalização de precarização e diminuição do emprego formal no Brasil;98

c) a rápida tramitação na Câmara da chamada Reforma da Previdência, PEC 287/2016,99 que estabelece uma ampla modificação no sistema de previdência e seguridade social no Brasil, especialmente estabelecendo como idade mínima para a aposentadoria, de homens e mulheres, urbana e rural, a idade de 65 anos;

d) a igualmente rápida tramitação do Projeto de Lei $6787 / 2016^{100}$, chamado de Reforma trabalhista, que tem o condão de modificar profundamente o conjunto de legislações, garantias e direitos trabalhistas existentes atualmente no Brasil. De acordo com

\footnotetext{
${ }^{97}$ Disponível em: < https://www25.senado.leg.br/web/atividade/materias/-/materia/127337 >. Acesso em: 18 maio 2017. A Emenda tem o objetivo de frear os gastos públicos, fixando, por até 20 anos um limite para as despesas: será o gasto realizado no ano anterior corrigido pela inflação - em termos reais fica praticamente. A medida irá valer para os três Poderes - Executivo, Legislativo e Judiciário, e atinge áreas como saúde, educação e segurança. 0 texto inclui um mecanismo que pode levar ao congelamento do valor do salário mínimo, que seria reajustado apenas segundo a inflação: se o Estado não cumprir o teto de gastos da PEC, fica vetado a dar aumento acima da inflação com impacto nas despesas obrigatórias. Como o salário mínimo está vinculado atualmente a benefícios da Previdência, o aumento real ficaria proibido.

98 Disponível em: < http://www2.camara.leg.br/camaranoticias/noticias/TRABALHO-EPREVIDENCIA/526747-CAMARA-APROVA-TERCEIRIZACAO-PARA-TODAS-AS-ATIVIDADES-DA-EMPRESA.html >. Acesso em: 12 maio 2017.

${ }_{99}$ Disponível em: < http://www.camara.gov.br/proposicoesWeb/fichadetramitacao?idProposicao=2119881 $>$. Acesso em: 12 maio 2017.

100 Disponível em: < http://www.camara.gov.br/proposicoesWeb/fichadetramitacao?idProposicao=2122076 >. Acesso em: 12 maio 2017.
} 
ULTRALIBERALISMO, EVANGELICALISMO POLÍTICO E MISOGINIA: A FORÇA TRIUNFANTE DO PATRIARCALISMO NA SOCIEDADE BRASILEIRA PÓS-IMPEACHMENT MAIQUEL ÂNGELO DEZORDI WERMUTH JOICE GRACIELE NIELSSON

Moroni (2017, p. 9), "num país com um sindicalismo ainda frágil, parte dele atendendo aos interesses dos patrões, os acordos dificilmente irão além dos direitos já conquistados na CLT. Em outras palavras, os acordos vão retirar direitos";

e) a tramitação da Proposta de Emenda Constitucional $n^{\circ} 215^{101}$, que retira do Executivo o poder de demarcação de terras indígenas, equiparando "as terras tradicionais às propriedades rurais, podendo ser arrendadas, divididas e receber 'investimentos' dos agronegócio e das mineradoras" (MORONI, 2017, p. 9), medida essa paralela ao desmonte da política de saúde indígena e à redução do orçamento da FUNAI, o menor em dez anos;

f) a reforma da educação em todos os níveis, alavancada pelos adeptos da chamada "escola sem partido", o que perpassa pela reforma do ensino médio via medida provisória, retomando a distinção entre ensino "científico" e "técnico", pela reforma do ensino fundamental, com a retirada de disciplinas críticas do currículo, e pelo encolhimento das universidade públicas e enfraquecimento dos Institutos Federais de Educação.

Enfim, afirma Céli Jardim Pinto ${ }^{102}$, no Brasil, a crise política que resultou no impeachment de Dilma Rousseff, "insuflada pela grande mídia, somada à crise econômica [...] criaram um caldo de cultura perfeito para a sensação de insegurança e caos no país, que funciona como um freio à vida política, à participação e à mobilização”. É, portanto, um cenário de profunda insegurança, cuja resposta é oferecida pelo discurso religioso e fundamentalista. Interessante observar, afirma Fraser, ${ }^{103}$ que "o evangelicalismo não dá segurança de forma real. $\mathrm{Na}$ verdade, dá às pessoas um discurso e um conjunto de práticas através das quais elas podem gerir a insegurança”.

O evangelicalismo parte da seguinte premissa: "você é um pecador, você vai fracassar, você pode perder seu emprego, você pode beber demais, você pode ter um caso extraconjugal, seu marido pode te abandonar, seus filhos podem usar drogas. Mas está tudo bem. Deus ainda te ama e a tua igreja te aceita"104. O efeito é, em parte, transmitir aceitação, mas também

\footnotetext{
101 Disponível em: < http://www.camara.gov.br/proposicoesWeb/fichadetramitacao?idProposicao=14562>. Acesso em: 12 maio 2017.

102 PINTO, Céli Jardim. Onde está o povo? 2017. Disponível em: <http://www.sul21.com.br/jornal/ondeesta-o-povo/>. Acesso em: 13 abr. 2017.

103 FRASER, Nancy. Mapeando a imaginação feminista: da redistribuição ao reconhecimento e à representação. Estudos Feministas, v. 15, n. 2, p. 240, Florianópolis, maio/ago. 2007, p. 303.

104 FRASER, Nancy. Mapeando a imaginação feminista: da redistribuição ao reconhecimento e à representação. Estudos Feministas, v. 15, n. 2, p. 240, Florianópolis, maio/ago. 2007, p. 303.
} 
ULTRALIBERALISMO, EVANGELICALISMO POLÍTICO E MISOGINIA: A FORÇA TRIUNFANTE DO PATRIARCALISMO NA SOCIEDADE BRASILEIRA PÓS-IMPEACHMENT MAIQUEL ÂNGELO DEZORDI WERMUTH JOICE GRACIELE NIELSSON

preparar as pessoas para os problemas de tempos difíceis, oferecendo um discurso acolhedor e de esperança.

Constantemente invocando a possibilidade de haver problemas, toda e qualquer espécie de crise, "o evangelicalismo incute sentimento de insegurança em seus seguidores mesmo quando parece oferecer-lhes uma maneira de lidar com ele"105 no que cabe retomar Foucault, a fim de compreendermos que "o evangelicalismo é uma tecnologia do cuidado-de-si que é especialmente adaptada ao neoliberalismo na medida em que este está sempre gerando insegurança” ${ }^{106}$. Segundo Céli Pinto ${ }^{107}$,

as pessoas aderem a estas religiões porque elas respondem algumas necessidades importantes. Dentro delas os excluídos e os (des) incluídos cada vez mais encontram um sentimento de pertencimento a eles negados, de fraternidade, de ter no "irmão" ou na "irmã" de fé um seu igual. É no grande templo ou na pequena igreja que as pessoas encontram a esperança.

É, portanto uma aliança estratégica que dá sustentação ao patriarcalismo: a implantação de políticas ultraliberais gera inseguranças cada vez maiores, que são respondidas e acolhidas pelo discurso religioso conservador. Ambas apregoam um discurso moral reacionário de responsabilidade individual, em que cada um colhe o que plantou, sem que se olhe para as circunstâncias, e qualquer solidariedade é banida, porque atrapalha tal pedagogia. Tanto a crise, quanto a salvação econômica e a salvação espiritual são atribuídas às escolhas e atitudes individuais de cada um.

Nesta engrenagem, evangelicalismo político e capitalismo neoliberal possuem uma íntima relação. Especialmente a partir do avanço da crise do capitalismo estrutural, em meados dos anos 1970, proliferaram iniciativas de reestruturação de formas de produção material da vida, que passaram a capturar a subjetividade mediante uma percepção da realidade marcada pelo atomismo do sujeito. A partir deste atomismo, a questão da diferença na conflituosidade acaba dissolvida na indiferença; a experiência no mundo da mercadoria e do consumo faz com que diferenças sejam diluídas em diversidades indiferentes. Neste cenário de extrema complexidade e incertezas, o saber religioso penetra profundamente nas massas e afeta o movimento feminista, bem como a outros movimentos críticos e de minorias, elevando significativamente os níveis de moralidade, de preconceito e de fundamentalismo.

105 FRASER, Nancy. Mapeando a imaginação feminista: da redistribuição ao reconhecimento e à representação. Estudos Feministas, v. 15, n. 2, p. 240, Florianópolis, maio/ago. 2007.

106 FRASER, Nancy. Mapeando a imaginação feminista: da redistribuição ao reconhecimento e à representação. Estudos Feministas, v. 15, n. 2, p. 240, Florianópolis, maio/ago. 2007, p. 303.

107 PINTO, Céli Jardim. Onde está o povo? 2017. Disponível em: < http://www.sul21.com.br/jornal/ondeesta-o-povo >. Acesso em: 13 abr. 2017. 
O discurso religioso, ainda, é responsável por realizar a grande virada ideológica deste processo, ao imputar toda a insegurança gerada por este cenário, ao avanço do reconhecimento de direitos a grupos minoritários. Politicamente a "bancada evangélica" se alia às formas conservadoras, associadas ao patriarcalismo, promovendo a hegemonia de padrões androcêntricos e heteronormativos, bem como o desmonte das políticas sociais de seguridade e proteção, no esteio do discurso ultraliberal.

Deste modo, o próprio “evangelicalismo político" contribui para a construção de um cenário de inseguranças e incertezas. Por outro lado, mediante uma profunda retórica antiprogressista, atribui as incertezas ao avanço de valores "antifamiliares", como o aborto, o casamento gay, a transexualidade, dentre outros, oferecendo às pessoas um conjunto de práticas por meio das quais elas podem gerir a insegurança e a incerteza. Opera, portanto, uma inversão perversa, e exitosa, no discurso.

Nesse sentido, o patriarcalismo utiliza de forma bem-sucedida uma retórica antifeminista e antiprogressista de reconhecimento para esconder a política de redistribuição e o desmantelamento dos direitos sociais, e inclusive, da própria institucionalidade democrática do país. Temas como a proibição do debate sobre a suposta “ideologia de gênero" na escola, que se consolidou na retirada da obrigatoriedade dos estudos sobre gênero da base curricular nacional, a tentativa de criminalização do aborto em caso de estupro, ao mesmo tempo em que a cultura do estupro avança desenfreadamente, os debates em torno do Estatuto da Família, e mesmo a polêmica gerada pela inserção da frase de Simone de Beauvoir no Exame Nacional do Ensino Médio (ENEM), no ano de 2015, o que gerou atos de “protestos" Brasil afora, estão na base da política de reconhecimento antifeminista, e antiprogressista apregoada pelo evangelicalismo.

Este movimento, aduz Fraser, ${ }^{108}$ parte do sucesso obtido pelas forças conservadoras em mostrar as feministas e outros movimentos progressistas como profissionais de elite e humanistas seculares que desprezam as mulheres comuns, especialmente as trabalhadoras e religiosas. No Brasil, este fenômeno é visível nas massivas campanhas que buscam atribuir às feministas, e a outros integrantes de movimentos progressistas, como os defensores dos direitos humanos, a pecha de inimigas das famílias, uma vez que defendem o aborto, a liberdade sexual e o casamento homoafetivo, dentre ouros, de inimigas da maternidade, pois defendem o direito de escolha da mulher diante desta possibilidade, inimigas dos homens, porque desejariam tomar 0 poder deste, dentre vários outros argumentos bastante conhecidos.

${ }^{108}$ FRASER, Nancy. Fortunas del feminismo. Traficantes de Sueños: Madrid, 2015. 
ULTRALIBERALISMO, EVANGELICALISMO POLÍTICO E MISOGINIA: A FORÇA TRIUNFANTE DO PATRIARCALISMO NA SOCIEDADE BRASILEIRA PÓS-IMPEACHMENT MAIQUEL ÂNGELO DEZORDI WERMUTH JOICE GRACIELE NIELSSON

Ora, aduz Fraser, ${ }^{109}$ apesar desta visão do feminismo ser patentemente falsa, o fato é que este "falhou ao tentar alcançar estratos das mulheres trabalhadoras e de classe baixa, atraídas na última década para a cristandade evangélica". Focadas apenas na política de reconhecimento, falhamos na tentativa de entender como a orientação religiosa delas responde às suas posições e necessidades sociais: “As classes populares foram abandonadas pela esquerda, que nos últimos anos esteve excessivamente preocupada em salvar a pele, em um jogo político completamente descolado da vida real de pessoas que necessitam garantir a sobrevivência dia após dia" ${ }^{110}$.

Nesta espécie de vazio não preenchido pelo pensamento progressista, pode-se esclarecer, aduz Fraser, ${ }^{111}$ o poder de atração do evangelicalismo em relação "às mulheres pobres, trabalhadoras e religiosas". Tais mulheres, afirma a autora, por um lado, subscrevem a uma ideologia conservadora de domesticidade tradicional, mas por outro não vivem de fato vidas patriarcais, sendo a maioria ativa no mercado de trabalho e relativamente empoderada na vida familiar. No entanto, acabam tirando algo significativo da ideologia patriarcalista, especialmente do evangelicalismo, algo que thes confere sentido à vida e alento diante das incertezas e das dificuldades que, possivelmente, virão.

Céli Pinto ${ }^{112}$ sintetiza afirmando que o discurso progressista não consegue chegar até a massa do povo brasileiro, que não está nos movimentos sociais, não está nos sindicatos, não tem TV fechada, não vai às manifestações, não lê blogs alternativos. Enormes parcelas da população já não têm nenhum direito trabalhista, trabalha por empreitada, ganhando dinheiro vivo no fim do dia, são trabalhadores informais, no máximo terceirizados ou empreendedores individuais. Para uma enorme parcela da população brasileira a política é algo "sujo e distante" que não "serve para nada". Os políticos só defendem seus próprios interesses. Os partidos políticos não fazem sentido.

Neste vazio inominado, não reconhecido e muitas vezes não percebido pelos movimentos críticos, a espiral de auxílio mútuo promovido pelo evangelicalismo político apoia e promove o avanço de políticas sociais ultraliberais, geradoras de incertezas e dificuldades para a vida das pessoas, oferecendo, pela via do discurso religioso, uma resposta a tal insegurança, e

109 FRASER, Nancy. Mapeando a imaginação feminista: da redistribuição ao reconhecimento e à representação. Estudos Feministas, v. 15, n. 2, p. 240, Florianópolis, maio/ago. 2007, p. 301.

110 PINTO, Céli Jardim. Onde está o povo? 2017. Disponível em: < http://www.sul21.com.br/jornal/ondeesta-o-povo/ >. Acesso em: 13 abr. 2017.

111 FRASER, Nancy. Mapeando a imaginação feminista: da redistribuição ao reconhecimento e à representação. Estudos Feministas, v. 15, n. 2, p. 240, Florianópolis, maio/ago. 2007, p. 302.

112 PINTO, Céli Jardim. Onde está o povo? 2017. Disponível em: < http://www.sul21.com.br/jornal/ondeesta-o-povo/ >. Acesso em: 13 abr. 2017. 
ULTRALIBERALISMO, EVANGELICALISMO POLÍTICO E MISOGINIA: A FORÇA TRIUNFANTE DO PATRIARCALISMO NA SOCIEDADE BRASILEIRA PÓS-IMPEACHMENT MAIQUEL ÂNGELO DEZORDI WERMUTH JOICE GRACIELE NIELSSON

ao mesmo tempo atribuindo tais incertezas ao avanço de políticas progressistas de concessão de direitos a grupos tradicionalmente discriminados. É, portanto, o grande eixo de sustentação do patriarcalismo que avança triunfantemente no cenário brasileiro atual.

\section{CONCLUSÃO}

O presente artigo perspectivou o cenário político-social brasileiro posterior ao processo de impeachment da ex-Presidenta Dilma Rousseff, em 2016, buscando evidenciar os seus impactos. A partir da pesquisa empreendida, foi possível evidenciar que o problema de pesquisa formulado na introdução pode ser respondido afirmativamente, o que significa dizer que o referido processo de impedimento foi responsável pela rearticulação de forças que permitiram a retomada e o avanço da agenda do patriarcalismo no país.

Essa retomada, segundo se procurou demonstrar ao longo do texto, foi possível graças à aliança firmada entre ultraliberais e fundamentalistas que tem sido responsável pela implementação de políticas que se configuram como uma estratégia de desmonte do Estado Social que foi minimamente estruturado no Brasil a partir do início do século.

Para uma melhor compreensão do fenômeno, o artigo resgatou da teoria socialdemocrática de Nancy Fraser o conceito de “evangelicalismo político”, ferramenta conceitual que permitiu compreender como a aliança acima mencionada foi viabilizada, bem como a retomada de pautas extremamente conservadoras que tem sido responsáveis pelo retrocesso em políticas sociais que até meados de 2016 pareciam estar consolidadas no país e que, a partir do impedimento, passaram e/ou estão passando por reformulações drásticas que, em muitos casos, significam a sua derrocada.

Nesse sentido, buscou-se evidenciar que o evangelicalismo atribui às forças progressistas em movimento no país antes do processo de impedimento a responsabilidade pela insegurança que a ocupação de determinados espaços pelas classes historicamente desfavorecidas - e que passaram a ter um certo protagonismo em virtude das políticas inclusivas implementadas - gerou nas classes detentoras de espaços privilegiados de poder.

O evangelicalismo político, como se procurou demonstrar, surge, então, no Brasil, como responsável pelo bloqueio ao avanço das forças progressistas e à concessão de direitos a grupos historicamente excluídos, utilizando-se uma retórica codificada de gênero a fim de sustentar a retirada de direitos e a retomada de políticas extremamente austeras. Essa retórica codificada de gênero, inclusive, ficou muito evidente no slogan "tchau, querida", clara referência ao 
caráter misógino que permeou todas as discussões que culminaram com o impedimento de Dilma.

A partir destas análises, conclui-se que os movimentos progressistas necessitam recuperar a visão integral da realidade, superando as disputas e fragmentações internas e atuando nos campos econômico, político e cultural, a fim de reconstruir uma alternativa ética e um referencial político capaz de superar o déficit de empoderamento feminino na sociedade brasileira, superando as fragilidades dos feminismos e dos movimentos progressistas e recuperando o potencial crítico e emancipatório necessário para fazer frente ao avanço patriarcalista, alimentado pelo ultraliberalismo e pelo evangelicalismo político denunciado por Nancy Fraser.

\section{REFERÊNCIAS}

AMORÓS, Célia. Hacia uma crítica de la razón patriarcal. Barcelona: Anthropos, 1997.

BAUMAN, Zygmunt. Estranhos à nossa porta. Rio de Janeiro: Zahar, 2017.

BIROLLI, Flávia. GERALDES, Elen Cristina [et. al] (Orgs). Mídia, misoginia e golpe. Brasília: FACUnB, 2016.

BLANCO, Ramon. A doutrina de choque temerária. Le Monde Diplomatique Brasil, ano 10, $\mathrm{n}^{\circ}$ 116, p. 11, mar. 2017.

BOITEUX, Luciana. Misoginia no golpe. In: PRONER, Carol. [et. al.] (orgs). A Resistência ao Golpe de 2016. Bauru: Canal 6, p. 261-266, 2016.

BUTLER, Judith. Cuerpos que importan: sobre los límites materiales y discursivos del "sexo". 1. ed. Buenos Aires: Paidós, 2002.

BUTLER, Judith. Fundamentos contingentes: o feminismo e a questão do "pós-

modernismo". Cadernos Pagu, n. 11, vol. 11-42, 1998.

BUTLER, Judith. Problemas de Gênero: Feminismo e subversão da identidade. 3. ed. Rio de Janeiro: Civilização Brasileira, 2010.

BUTLER, Judith. Vida Precária: el poder del duelo y la violencia. Buenos Aires: Paidós, 2009.

CHALHOUB, Sidney. Trabalho, lar e botequim: o cotidiano dos trabalhadores no Rio de Janeiro da belle époque. 2. ed. Campinas: UNICAMP, 2001.

ESTÉS, Clarisse Pinkola. Mulheres que correm com os lobos. Rio de Janeiro: Rocco, 1999.

FIRESTONE, Sulamith. Dialéctica del sexo. Barcelona: Kairos, 2009. 
FRASER, Nancy. Fortunas del feminismo. Traficantes de Sueños: Madrid, 2015.

FRASER, Nancy. Mapeando a imaginação feminista: da redistribuição ao reconhecimento e à representação. Estudos Feministas, v. 15, n. 2, p. 240, Florianópolis, maio/ago. 2007.

FRASER, Nancy. O feminismo, o capitalismo e a astúcia da história. Mediações, v. 14, n. 2, p. 11-33, Londrina, jul./dez. 2009.

FRIEDAN, Betty. Mística feminina. Petrópolis: Vozes, 1971.

FLORES, Joaquín Herrera. De habitaciones propias y otros espacios negados: una teoría crítica de las opresiones patriarcales. Bilbao: Instituto de Derechos Humanos Universidad de Deusto, 2005.

GRUBBA, Leilane Serratine; AQUINO, Sérgio Fernandes. O individualismo e patriarcalismo dos direitos humanos como marco da ideologia-mundo. Revista do Programa de Pós-Graduação em Direito da UFC, v. 36, n. 2, jul./dez. 2016.

OKIN, Susan. Liberalismo político, justicia y género. In: CASTELLS, C. (Org.). Perspectivas feministas en teoría política. Barcelona: Paidós, 1996.

PINTO, Céli Jardim. Onde está o povo? 2017. Disponível em: < http://www.sul21.com.br/jornal/onde-esta-o-povo >. Acesso em: 13 abr. 2017.

RANCIÈRE, Jacques. O ódio à democracia. São Paulo: Boitempo, 2014.

SALIBA, Maurício Gonçalves; SANTIAGO, Brunna Rabelo. Bailarinas não fazem política? Análise da violência de gênero presente no processo de impeachment de Dilma Rousseff. Revista Direitos Fundamentais e Democracia, v. 21, n. 21, p. 91-105, dez. 2016.

SANTOS, Boaventura de Sousa. A difícil democracia: reinventar as esquerdas. São Paulo: Boitempo, 2016.

SANTOS, Boaventura de Sousa. Os perigos da desordem jurídica no Brasil. In. PRONER, Carol; CITTADINO, Gisele; TENENBAUM, Marcio; RAMOS FILHO, Wilson. A resistência ao golpe de 2016. São Paulo: Projeto Editorial Praxis, 2016.

SEGATO, Rita Laura. La guerra contra las mujeres. Madrid: Traficantes de Sueños, 2016.

SILVA, Adriano Correia. Um fascismo liberal exótico e a nostalgia do Brasil Colônia. Revista do Instituto Humanitas UNISINOS, $n^{\circ}$ 490, ano XVI, p. 54-59, ago. 2016.

SILVA, Maurício Roberto da; PIRES, Giovani de Lorenzi; PEREIRA, Rogérios Santos. O Congresso Nacional, a mídia e as questões de gênero no limiar da "primavera das mulheres”. Motrivivência, v. 27, n. 46, p. 6-14, Florianópolis, dez. 2015.

SCHWARCZ, Lilia M.; STARLING, Heloisa M.. Brasil: uma biografia. São Paulo: Companhia das Letras, 2015. 
ULTRALIBERALISMO, EVANGELICALISMO POLÍTICO E MISOGINIA: A FORÇA TRIUNFANTE DO PATRIARCALISMO NA SOCIEDADE BRASILEIRA PÓS-IMPEACHMENT MAIQUEL ÂNGELO DEZORDI WERMUTH JOICE GRACIELE NIELSSON

TELES, Edson. Na dissimulação democrático-liberal, o fascismo apresenta suas armas. Revista do Instituto Humanitas UNISINOS, $\mathrm{n}^{\circ}$ 490, ano XVI, p. 60-64, ago. 2016.

TIBURI, Márcia. A Máquina Misógina e o Fator Dilma Rousseff na Política Brasileira. Revista Cult, 2016. Disponível em: < http://revistacult.uol.com.br/home/2016/07/a-maquina-misogina-e-ofator-dilma-rousseff-na-politica-brasileira >. Acesso em: 10 abr. 2017.

TIBURI, Márcia. Dilma, Janaína e “Gaslighting”. Revista Cult, 2016. Disponível em: < http://revistacult.uol.com.br/home/2016/04/dilma-janaina-e-gaslighting >. Acesso em: 10 abr. 2017.

TODOROV, Tzvetan. Os inimigos íntimos da democracia. Tradução de Joana Angélica d’Avila Melo. São Paulo: Companhia das Letras, 2012.

\section{COMO FAZER A REFERÊNCIA DO ARTIGO (ABNT):}

WERMUTH, Maiquel Ângelo Dezordi; NIELSSON, Joice Graciele. Ultraliberalismo, evangelicalismo político e misoginia: a força triunfante do patriarcalismo na sociedade brasileira pós-impeachment.Revista Eletrônica do Curso de Direito da UFSM, Santa Maria, RS, v. 13, n. 2, p. 455-488, ago. 2018. ISSN 1981-3694. Disponível em: < https://periodicos.ufsm.br/revistadireito/article/view/27291 >. Acesso em: dia mês. ano. doi: http://dx.doi.org/10.5902/1981369427291 . 